NBER WORKING PAPER SERIES

LIQUIDITY RISK AND U.S. BANK LENDING AT HOME AND ABROAD

\author{
Ricardo Correa \\ Linda S. Goldberg \\ Tara Rice
}

Working Paper 20285

http://www.nber.org/papers/w20285

\author{
NATIONAL BUREAU OF ECONOMIC RESEARCH \\ 1050 Massachusetts Avenue \\ Cambridge, MA 02138 \\ July 2014
}

The authors thank Jason Goldrosen for excellent research assistance, as well as Claudia Buch, Ben Craig, Katheryn Russ, Charles Thomas, and participants at the International Banking Research Network workshops in Potsdam and Paris for thoughtful suggestions. The views expressed in this paper are solely those of the authors and should not be interpreted as reflecting the view of the Board of Governors, Federal Reserve Bank of New York, the staff of the Federal Reserve System, or the National Bureau of Economic Research.

NBER working papers are circulated for discussion and comment purposes. They have not been peerreviewed or been subject to the review by the NBER Board of Directors that accompanies official NBER publications.

(C) 2014 by Ricardo Correa, Linda S. Goldberg, and Tara Rice. All rights reserved. Short sections of text, not to exceed two paragraphs, may be quoted without explicit permission provided that full credit, including $(\mathrm{C}$ notice, is given to the source. 
Liquidity Risk and U.S. Bank Lending at Home and Abroad

Ricardo Correa, Linda S. Goldberg, and Tara Rice

NBER Working Paper No. 20285

July 2014

JEL No. F3,G21,G38

\begin{abstract}
$\underline{\text { ABSTRACT }}$
While the balance sheet structure of U.S. banks influences how they respond to liquidity risks, the mechanisms for the effects on and consequences for lending vary widely across banks. We demonstrate fundamental differences across banks without foreign affiliates versus those with foreign affiliates. Among the nonglobal banks (those without a foreign affiliate), cross-sectional differences in response to liquidity risk depend on the banks' shares of core deposit funding. By contrast, differences across global banks (those with foreign affiliates) are associated with ex ante liquidity management strategies as reflected in internal borrowing across the global organization. This intra-firm borrowing by banks serves as a shock absorber and affects lending patterns to domestic and foreign customers. The use of official-sector emergency liquidity facilities by global and nonglobal banks in response to market liquidity risks tends to reduce the importance of ex ante differences in balance sheets as drivers of cross-sectional differences in lending.
\end{abstract}

Ricardo Correa

Board of Governors of the

Federal Reserve System

Division of International Finance

Washington DC 20551

ricardo.correa@frb.gov

Linda S. Goldberg

Federal Reserve Bank-New York

33 Liberty Street

New York, NY 10045

and NBER

linda.goldberg@ny.frb.org
Tara Rice

Board of Governors of the

Federal Reserve System

Division of International Finance

Washington DC 20551

tara.n.rice@frb.gov 


\section{Introduction}

The recent financial crisis underscored the importance of understanding the ways in which liquidity conditions influence credit extension to domestic and foreign customers. We investigate the distinctions between responses to liquidity risks across two types of large U.S. banks, those that are domestically oriented and those that are more global in the sense of having affiliates in foreign countries. As these banks have widely different business models, the channels and magnitude of transmission of shocks into bank lending should differ significantly by bank type. Small domestic banks have been shown to have relatively strong lending responses to liquidity shocks (Kashyap and Stein 2000). Banks with foreign affiliates, particularly large banks, have been shown to actively move funds across their organizations in response to such shocks, potentially insulating lending in their home markets but transmitting shocks abroad (Cetorelli and Goldberg 2012a). For both types of banks, changes in market liquidity conditions are likely to influence lending differently in crisis periods than in normal (or non-crisis) periods, in part due to their willingness to use liquidity provided through official sector facilities.

The extant literature shows that changing liquidity conditions alter the loan growth rates and liquid asset mix within U.S. banks, and that differences documented within groups of large and small U.S. banks relate to their ex ante balance sheet compositions (Cornett, McNutt, Strahan and Tehranian 2011). ${ }^{1}$ However, the links between liquidity risk and banks' activities warrant additional consideration in (at least) three ways. First, banks have distinct channels through which they may adjust their balance sheets in response to liquidity strains. Loan growth effects may differ across domestic and foreign customers. Also, for global banks, loan activity within the organization and across affiliated banks may adjust, providing an extra margin of response than can change the incidence of effects on domestic versus foreign customers (Cetorelli and Goldberg 2012a).

\footnotetext{
${ }^{1}$ There is a growing literature on the link between liquidity shocks and bank lending using micro data. The prime example is Khwaja and Mian (2008), who focus on the effect of changes in banks' access to funding on their domestic lending. Schnabl (2012) adds to this literature by exploring the differential effect of funding shocks on banks affiliated with global institutions and those that are purely domestic but that rely on foreign financing. Cetorelli and Goldberg (2012b) and Correa, Sapriza, and Zlate (2013) have studied the transmission of liquidity shocks across borders through the activities of branches of global banks. However, none of these studies have analyzed the effect of funding shocks and bank balance sheet characteristics on the international activities of global banks.
} 
Second, these effects hitting the parent bank are not likely to transmit to the same degree across all the foreign countries they interact with: global banks differentiate across countries when they adjust their international exposures after a liquidity shock. The magnitude and direction of adjustments depend on the business models of the respective banks (Cetorelli and Goldberg 2012b). Some affiliate locations are more important for the investment strategies of the whole organization, while other locations are more important for funding the organization.

Third, the effects of liquidity risk on lending will differ during non-crisis and crisis periods. The effects of the price of liquidity are likely to depend importantly on whether public (or official) sector sources of liquidity are a competitively priced option for financial firms. As Buch and Goldberg (2014) show, empirical studies of the effects of liquidity risk on bank adjustments should control both for bank characteristics and the use of official sector liquidity facilities. As market liquidity conditions deteriorate, weaker banks initially face the tightest constraints from private sector funding sources. As banks turn to publically-provided liquidity, this relieves some of the adjustment pressures associated with the elevated cost of liquidity from private sources. These points need to be addressed, if possible, in econometric specifications.

All these themes motivate, and are addressed by, the analysis of the present paper on the experiences of U.S. banks. Our study is part of a broader initiative, described in Buch and Goldberg (2014), in which researchers in eleven countries participating in the International Banking Research Network (IBRN) independently analyze the effects of liquidity risk through the cross-section of banks operating in their own countries. ${ }^{2}$ The teams of researchers use confidential data from regulatory reports filed within their countries, and then apply a common empirical methodology that follows closely on two building blocks. The first methodological building block is Cornett, McNutt, Strahan and Tehranian (2011, hereafter CMST2011) who examine the role of ex ante bank balance sheet composition in explaining the ex post differences across U.S. banks in their adjustment to liquidity risk conditions. Our paper is closest to that building block as we also focus on the sample of U.S. banks, albeit using a longer period of time for the analysis (from 2006 through 2012, instead of through 2009). However, our work is distinguished in a number of substantive dimensions. We concentrate only on the large U.S. banks, distinguish between those banks without versus those with foreign affiliates, and we focus

\footnotetext{
${ }^{2}$ Related studies were conducted by teams from Austria, Australia, Canada, France, Germany, Hong Kong, Ireland, Italy, Poland, and the United Kingdom.
} 
more pointedly on different counterparties in the credit extension by these banks. We introduce explicit treatment of international linkages through funding and lending of individual banks with both their related and unrelated counterparties at home and abroad. In addition, we explicitly examine how use of official sector liquidity facilities alters which balance sheet characteristics of financial institutions drive differences in the transmission of liquidity risk to loan and credit growth. The relative importance of the balance sheet characteristics evolve when official liquidity facilities are accessed, with corresponding implications for the transmission of liquidity shocks internationally through banks.

The second methodological building block is Cetorelli and Goldberg (2012c), who demonstrate that the business models of global banks and the characteristics of destination countries, as investment or funding locations, drive their relative importance in banks' internal capital markets adjustment to shocks for individual banks. We build on those results by combining bank balance sheet composition considerations with bank-destination considerations in a single econometric specification.

We confirm that elevated levels of liquidity risk have different effects on lending growth across large U.S. banks. The ex-ante balance sheet characteristics that matter for these different responses depend on whether or not the banks are global (have foreign affiliates). For nonglobal banks, the key balance sheet characteristic that explains cross-sectional differences in loan growth is the share of core deposits in bank funding, confirming one of the results in CMST2011 for large banks. By contrast, we find that differences in the transmission of liquidity risk into lending across global banks are more strongly associated with their organizational liquidity management strategies, as reflected in outstanding internal borrowing or lending with the rest of their organization. Net internal capital market borrowing increases in periods with increased liquidity risk for the U.S. banks that have higher outstanding unused commitments to their customers and lower Tier 1 asset shares. This higher net borrowing is associated with relatively more growth in domestic lending, foreign lending, credit, and cross-border lending. In all regression specifications, the roles of cross-sectional differences in bank balance sheets are diminished when liquidity risk conditions deteriorate substantially and banks access official sector liquidity.

Cross-border lending activity and internal borrowing and lending activity tend to be more volatile than domestic lending and lending conducted through U.S. bank affiliate offices abroad. 
The empirical model we test explains observed changes in domestic loan growth, as well as changes in internal capital market positions, but does not capture as much of the cross-border lending growth rates of U.S. banks. At the same time, differences across banks in cross-border lending activities are sensitive to more of the bank balance sheet characteristics than any of the other forms of lending. Our further investigation of drivers of cross-border and local lending disaggregated by international locations shows that the effects of liquidity risk on these locations vary considerably. Locations that are relatively important in the outstanding claims of the parent bank tend to be supported to a greater degree when liquidity risk rises. When official sector liquidity is used, different balance sheet characteristics matter compared with lower liquidity risk periods.

\section{Empirical Method}

As described in detail in Buch and Goldberg (2014), the first stage of our analysis explores the effect of banks' funding conditions on their loan growth and credit extension. We begin with the following regression specification:

$$
\Delta Y_{i t}=\gamma_{i}+\mu_{t}+\left(\beta^{0}+\beta^{1} L I B_{-} O I S_{t}\right) X_{i, t-1}+\left(\alpha^{0}+\alpha^{1} L I B_{-} O I S_{t} \cdot X_{i, t-1}\right) F_{i t}+\varepsilon_{i t}
$$

where $Y_{i t}$ is a set of bank $i$ balance sheet items that respond to funding availability. For our purposes, this set includes loans to domestic counterparties, various measures of loans to foreign counterparties, total credit extension, and net due to balances (which capture the net internal borrowing of the parent bank from its domestic and foreign affiliates). This set of variables provides a useful window into the real transmission of liquidity risk. $X_{i, t-1}$ is a vector of control variables that captures the degree to which a bank is exposed to liquidity risk through ex ante balance sheet composition and market access, as in CMST2011. These variables include the liquidity of a bank's on-balance-sheet assets, the funding sources of the bank, and a proxy for bank size. The interaction between these terms and the LIBOR over OIS spread $\left(\right.$ LIB_OIS $\left._{t}\right)$, which is used as a measure of overall liquidity in the financial system, reflect the sensitivity of these intermediaries' credit extension to funding risks in accordance with their balance sheet 
composition. $^{3}$ As the baseline regression model includes bank and time fixed effects, $\gamma_{i}$ and $\mu_{t}$, respectively, following Cornett et al (2011), the estimates of $\beta$ reflect the importance of balance sheet composition considerations as cross-sectional drivers of the response of the $Y_{i t}$ variables to liquidity risk. ${ }^{4}$

The measured effects of liquidity risk through these balance sheet channels included in equation (1) may be affected by the intervention of a lender of last resort. The use of official liquidity could mitigate some of the high costs of private market financing during the crisis, and change how the banks' manage their liquidity internally (through their affiliates) and externally (through the interbank market). In the case of the United States, the relevant official liquidity facilities for these banks include the Federal Reserve's discount window and the Term Auction Facility (TAF), both of which are discussed in more detail below. To account for the potential effect of the official liquidity provision econometrically, we add interaction terms between the $X_{i, t-1}$ variables described above and a measure of central bank intervention $F_{i t}$ (Facility), an indicator variable equaling 1 if a bank accessed the discount window or the TAF in period $t$. Essentially, this specification controls for the possibility that the effects of private measures of liquidity risk through balance sheet channels are biased indicators of bank-specific liquidity constraints during periods characterized by use of central bank facilities. Formal tests of this sensitivity are via the coefficient $\alpha^{1}$ in equation (1), while the overall sensitivity of the balance sheet to liquidity risk in periods of central bank facility use is captured by $\beta^{1}+\alpha^{1}$.

The second stage of our analysis considers in greater detail the incidence of transmission of liquidity risk to foreign countries through different types of claims extended. For this purpose we exploit detailed information on the claims of parent banks on related and unrelated counterparties in foreign countries. We estimate a modified version of (1) which permits each bank to adjust its activities in different countries depending on the strategic importance of those locations to that bank. Formally, we estimate the following equation:

\footnotetext{
${ }^{3}$ These specifications trace the effects of liquidity risk on the composition of bank balance sheets. In addition to quantity adjustments, liquidity risk also can be reflected in the terms of loans and credit commitments to customers, as shown in Bord and Santos (2014).

${ }^{4}$ We run alternative specifications excluding bank fixed effects. In those specifications the $\beta$ s capture both absolute and cross-sectional differences in balance sheet composition.
} 


$$
\begin{aligned}
\Delta Y_{i t}^{c} & =\gamma^{i}+\mu_{t}^{r}+\left(\beta^{0}+\beta^{1} L I B_{-} O_{t}+\beta_{t}+\beta_{i, t-1}^{c}+\beta^{3} L I B_{-} O_{t} \cdot X_{i, t-1}^{c}\right) X_{i, t-1} \\
& +\left(\alpha^{1} L I B_{-} O I S_{t}+\alpha^{3} L I B_{-} O I S_{t} \cdot X_{i, t-1}^{c}\right) X_{i, t-1} \cdot F_{i t}+\varepsilon_{i t}
\end{aligned}
$$

In specification (2) the dependent variable is a claim of bank $i$ on a resident of country $c$ at time $t$, which can take the form of cross-border lending (claims) or local claims extended through overseas branches or subsidiaries. We follow Cetorelli and Goldberg (2012c) and construct measures of each country $c$ as an investment or funding location for each bank $i\left(X_{i, t-1}^{c}\right)$, with the investment variable essentially capturing the scale of bank claims in each country relative to the sum across all countries and the funding variable capturing the extent to which affiliate balance sheets are locally funded. As in the previous specification, we test for the significance of the sensitivity of foreign claims to liquidity risk in periods with no use of Federal Reserve facilities $\left(\beta^{3}\right)$ and periods when the bank accessed these facilities $\beta^{3}+\alpha^{3}$. The estimating equation includes region-time fixed effects to absorb changes in demand conditions in each region $\left(\mu_{t}^{r}\right)$.

\section{Data}

The primary data for our empirical analysis is a panel dataset containing bank balance sheet and other financial information collected from a number of sources. We obtain income statement, balance sheet, and selected off-balance sheet data on bank holding companies from the FR Y-9C form filed quarterly as part of regulatory reporting in the United States. We use the Federal Financial Institutions Examination Council (FFIEC) 009 form for detailed information on the country-specific distribution of U.S. bank holding companies' claims on foreign residents. We focus on the period between the first quarter of 2006 and the fourth quarter of $2012 .^{5}$

We follow CMST2011 and compute the following dependent variables for specification (1): the change in loans during the quarter $t$ divided by beginning of period $(t-1)$ assets $\left(\Delta\right.$ Loans $\left._{i t}\right)$ and, the change in credit extension at $t$, which is the sum of loans plus undrawn commitments divided by the sum of total assets plus undrawn commitments at the beginning of

\footnotetext{
${ }^{5}$ We begin in 2006 due to data availability issues. The FFIEC 009 reporting form changed in 2006, with some relevant items not included in the form prior to 2006 . Hereafter, we use interchangeably the terms "bank holding company" and "bank", recognizing that the commercial banks represent only a portion of the holding company.
} 
the quarter $\left(\Delta\right.$ Credit $\left._{i t}\right) \cdot{ }^{6}$ Given our focus on international transmission channels, we use loans subdivided according to the domestic or foreign residence of the borrower. This residency split is available only for commercial and industrial (C\&I) loans, which represent about 20 percent of loans of both large banks without foreign affiliates and banks with foreign affiliates. Overall lending to foreign counterparties can take the form of cross-border claims (lending from an office outside of the country where the borrower resides) or foreign office claims (local lending from the foreign office), with the latter possible only when the bank has branches or subsidiaries established outside of the United States. In addition, we add a dependent variable relevant for global banks, which is the change in net borrowing (liabilities minus claims) between the lead commercial banking office of a bank holding company and its affiliates (domestic and foreign). The change in "Net Due To" of the bank is scaled by the beginning of period total assets $\left(\Delta\right.$ NetDueTo $\left._{i t}\right)$ and captures internal liquidity management within the banking organization both domestically and internationally.

The balance sheet characteristics identified as potentially influencing cross-sectional variation in liquidity conditions for individual banks include the beginning of period: fraction of a bank's portfolio of assets that is illiquid (IlliquidAssets ${ }_{i, t-1}$ ), ratio of unused commitments to commitments plus assets (Commitments $s_{i, t-1}$ ), fraction of the banking organization's balance sheet financed with core deposits $\left(\right.$ CoreDeposits $\left._{i, t-1}\right)$, banking organization's regulatory Tier 1 risk-based capital to asset ratio $\left(\right.$ Tier1Capital $\left._{i, t-1}\right)$, and the banking organization's Net Due To position relative to total liabilities $\left(\right.$ NetDueTo $\left._{i, t-1}\right)$. All specifications also introduce the log of total assets $\left(\right.$ Assets $\left._{i, t-1}\right)$ as a control variable. Each of these variables is included in the regressions individually and also interacted with the measure of aggregate liquidity conditions, which is the U.S. dollar LIBOR over OIS spread, calculated as the average, within a quarter, difference between the three-month U.S. dollar London Interbank Offer Rate (LIBOR) and the Overnight Indexed Swap (OIS) rate for Federal Funds. ${ }^{7}$

\footnotetext{
${ }^{6}$ Appendix Table 1 presents a detailed description of construction of each variable used in the empirical analysis.

${ }^{7}$ The LIBOR-OIS spread can be calculated in different currencies, and is available for most of the countries involved in the IBRN initiative, thus providing some degree of consistency across countries. It also correlates closely with a broader set of liquidity measures as shown in Drehmann and Nikolau (2010). An alternative measure
} 
The Federal Reserve announced a number of extraordinary official liquidity measures to address the strains in U.S. financial markets during the crisis. ${ }^{8}$ Since the cost of funds at official facilities was at times lower for banks than private market financing, we adjust the response of individual banks to market prices of liquidity in order to account for their official sector facility use. We collect data on the institutions that accessed the TAF and discount window by date and aggregate by consolidated banking organization. We assign a value of $F_{i t}=1$ to any institution that has a positive balance in these facilities within each quarter, with $F_{i t}=0$ otherwise.

Finally, we refine the sample of institutions and observations used in our time-series panel specifications. First, we restrict the sample to banks with more than $\$ 10$ billion in total assets (in 2012 dollars), drop non-bank financial institutions and reporters that were added in Q1 2009 (such as Goldman Sachs, Morgan Stanley, American Express, CIT, GMAC, and Metlife), and drop observations where the quarterly change in real total assets is greater than 10 percent to account for structure changes (such as mergers). We split the large banks in our sample into two groups: (1) non-global banks, which are those large banks without foreign affiliates; and (2) global banks, which are banks with branches or subsidiaries located in other countries. ${ }^{9}$ We also winsorize the dependent variables at the 1 and 99 percentiles.

Table 1 reports the summary statistics of select banks' financial statement items over the period 2006Q1 to 2012Q4. Panel A describes data at the bank holding company level, covering 95 banks each for up to 28 quarters. We have a total of 1920 bank-quarter observations, of which 1415 are for non-global banks and 505 observations pertain to banks with foreign affiliates. Panel A reports these statistics for all bank holding companies and quarters in the sample, and separately for banks with foreign affiliates and banks without foreign affiliates. Global banks are fewer in number, have a larger median size, and rely less on core deposits as a source of funding. Global banks are exposed to larger contingent loan demand shocks, as the ratio of unused commitments to total credit is larger, and actively borrow and lend within their broader organization, with liquidity management through internal capital markets reflected in the Net Due To rows. These differences across the banks with and without foreign affiliates will prove

is the TED spread, used in Cornett et al. (2011). However, the TED spread may incorporate credit risk associated with the creditworthiness of local sovereign debt. We thank Ben Craig for these insights.

${ }^{8}$ The full set of credit and liquidity measures is provided at http://www.federalreserve.gov/monetarypolicy/bst.htm

${ }^{9}$ This sample has a strong overlap with that described as large banks in Cornett et al (2011). That study set the large bank cutoff as banks with assets exceeding \$1billion. We choose the cutoff over bank holding company assets (as opposed to commercial bank assets), and have more comparability in size in our two groups of large banks. 
to be important in explaining cross-sectional variation in lending effects of liquidity shocks. In addition, cross-border claims and flows associated with internal liquidity management are more volatile than the domestic lending and the claims extended by foreign offices of U.S. banks.

Table 1 Panel B summarizes data that add a location dimension to the time and bankspecific dimensions already reported. Data are available with locational details for the banks that have significant international exposures either through lending cross-border to foreign residents or through claims via bank affiliate locations. Banks are exposed to more countries via crossborder claims compared with through affiliate locations. In addition, a larger number of banks hold cross-border claims than claims at their foreign affiliates. These differences and the crosscountry dimensionality of the data are reflected in the numbers of observations for analysis in each category, at 22,171 versus 5,911.

\section{Regression Results}

\subsection{Bank-level regressions.}

CMST2011 establish that diverse balance sheet structures are associated with diverse bank reactions to funding shocks with their study emphasizing differences across small and large U.S. banks. Our first set of estimations replicate their findings but use our sample of large banks, the longer time period, and refinements that capture international banking considerations and use of official sector liquidity. We further build on that work by dividing the group of large banks into those without foreign affiliates (Table 2 Panel A) and those with foreign affiliates (Table 2 Panel B), and by adding the various international dimensions for adjustment to changing liquidity risk conditions. Table 2 provides results for the estimated coefficients of equation (1) for changes in domestic C\&I loans, foreign C\&I loans, and credit (Panel A), with cross-border claims, foreign office claims, and Net Due To added for the banks with foreign affiliates (Panel B). The bottom section of each panel presents the implied marginal effects $\beta^{1}+\alpha^{1}$ of liquidity risk priced through the LIBOR-OIS spread and operating through bank balance sheet channels for periods in which individual institutions used central bank liquidity facilities. The sum $\beta^{1}+\alpha^{1}$ indicates the contribution of each right hand side variable to the cross-sectional differences in lending growth rates during periods when these banks are accessing a Federal Reserve liquidity facility. 
We find that banks' liquidity risk exposure through their balance sheet composition is associated with changes in their loan growth and credit extended, consistent with CMST2011. ${ }^{10}$ However, there are substantive differences between our results and CMST2011. For instance, we observe fewer statistically significant drivers of cross-sectional differences in lending and credit growth across banks. In banks without foreign affiliates, those with higher shares of core deposits in their funding mix, all else equal, are also those that sustain higher growth in domestic lending when liquidity risk rises (column 1). Illiquid asset shares, commitment ratios, and Tier 1 capital ratios do not contribute significant explanatory power to the cross-sectional differences in bank lending for this group of banks. During the crisis period when liquidity risk rises and some institutions use official sector sources of liquidity, ex ante balance sheet distinctions across banks no longer drive the cross-sectional difference in domestic loan growth rates in response to LIBOR-OIS. However, deposit funding shares matter for cross-sectional differences in credit growth and foreign lending during stress periods. The size and significance of the effects during these periods are presented in the lower rows of Table 2, Panel A. Particularly interesting is the sign pattern of these effects. Those banks with higher deposit shares provide relatively more support to credit and less support to foreign loans at times when they are accessing official sector liquidity, although facility use also raises the average level of foreign loans across banks relative to without facility use. Comparison of the R-squared statistics for these banks shows that the model does much better at capturing variation in domestic lending growth (adjusted $\mathrm{R}^{2}$ of 0.15 ) and credit growth (adjusted $\mathrm{R}^{2}$ of 0.18 ) than it does for variation in foreign lending growth (adjusted $\mathrm{R}^{2}$ of 0.02).

We conduct a simple exercise to assess the economic magnitude of these results in the sample of large banks without foreign affiliates. In particular, we assume an increase of 100 basis points in the LIBOR over OIS spread and compare its impact on banks located in the $25^{\text {th }}$ percentile and $75^{\text {th }}$ percentile of the distribution of those balance sheet characteristics that significantly affect bank lending. In the first set of results described above, core deposits are significant determinants of both domestic and foreign C\&I lending. Using the coefficient on the

\footnotetext{
${ }^{10}$ We have successfully replicated the Cornett et al. 2011 results for the types of samples of institutions, dependent variables, and time period they examine (tables not shown). In keeping with discussion in that study, we will not provide an interpretation of the reasons that $(\log )$ real assets may contribute to cross-sectional differences across banks in balance sheet adjustment to liquidity risk. In addition, while all of the reported regression specifications contain bank fixed effects, we also run and report the specifications excluding bank fixed effects Appendix Table 3). The findings reported in our text are robust to exclusion of bank fixed effects.
} 
interaction between core deposits and the LIBOR over OIS spread (0.007) reported in Panel A of Table 2, we find that a bank with a share of core deposits relative to total assets from the $25^{\text {th }}$ percentile of the distribution (58 percent) would lend \$211 million less in domestic C\&I loans compared with a bank with a deposit share at the $75^{\text {th }}$ percentile ( 76 percent). This difference is sizeable, as it represents about 9 percent of total domestic C\&I loans of the median bank (without foreign offices). ${ }^{11}$ At the same time, banks with more core deposits in their balance sheets would lend about $\$ 40$ million more to foreign residents as a results of the increase of 100 basis points in the LIBOR over OIS spread. These results confirm that the impact of liquidity risks on bank lending outcomes in relation to cross-sectional differences in balance sheet composition is economically important, but only through the deposit share distinction in this sample of banks.

Next, Table 2 Panel B presents the results of regression specifications for the large U.S. banks that have foreign affiliates, sometimes referred to as U.S. global banks. These regression specifications explain significantly more, at approximately 40 percent, of the time series and cross-sectional variation in domestic C\&I lending and credit growth. The model explains closer to 10 percent of the variation in C\&I lending to foreign resident borrowers, total cross-border lending, and lending by affiliate offices. This weak fit is despite the more substantial role that foreign lending plays in the global bank balance sheets. Foreign lending is 26 percent of global banks' C\&I lending compared with 1 percent for non-global banks. .

In global banks, internal liquidity management is a consistent driver of explaining crosssectional differences in loan growth in response to changing liquidity risk. Those banks with higher net borrowing from affiliated entities had consistently strong loan growth (domestic, foreign, cross-border, credit) when liquidity risks increased. As shown in the last column of Table 2 Panel B, these global banks with larger unused credit commitments borrow relatively more (net) from their affiliates when liquidity conditions worsen and then sustain lending to a greater degree.

Another interesting result is the way in which drivers of cross-sectional differences across the large global banks change when the global banks access official sector liquidity. Tier1 capital ratios gain importance, with higher capitalized banks lending and supporting credit to a

\footnotetext{
${ }^{11}$ To arrive at this dollar amount, we multiply the growth rate given by the product of the coefficient on the interaction term from Table 2 and the difference in the share of deposits of banks in the selected percentiles, by the total assets of the median bank in the sample of financial institutions that do not have any foreign affiliates.
} 
greater degree than less capitalized banks. When official liquidity is in use, the banks that have higher illiquid asset shares and more Tier 1 capital reduce net borrowing from foreign affiliates to a greater degree. The observation that higher internal capital market borrowing is used to support loan growth in global banks is consistent with evidence provided by Cetorelli and Goldberg (2012 b,c): the official liquidity provision may have helped insulate adverse international transmission to affiliated firms. The official liquidity also helped reduce transmission to foreign markets in banks that were relatively well capitalized and which also had relatively high shares of illiquid assets. Relatively high core deposit shares of banks were not associated with this same pattern of differences in activation of internal capital markets.

In terms of economic magnitudes, we replicate the quantitative analysis described above using information on the banks with foreign affiliates. First, we compare the difference in lending growth of a bank in the $75^{\text {th }}$ percentile of the Net Due To distribution (a ratio of Net Due To over Total Liabilities of 6.6 percent) to a bank in the $25^{\text {th }}$ percentile (a ratio of 1.2 percent) when there is a 100 basis point increase in the LIBOR over OIS spread. Banks in the higher part of the distribution support their domestic C\&I lending by about $\$ 800$ million more and support foreign C\&I lending by $\$ 167$ million more. These differences in lending represent about 5 percent and 27 percent of the lending done by the median bank in each category respectively, and are sizeable differences. The balance sheet differences in relation to liquidity risk transmission are even larger when we compare banks at different points of the Tier 1 capital ratio distribution during times when banks access official liquidity facilities. A bank in the $75^{\text {th }}$ percentile of the Tier 1 capital ratio distribution (a ratio of 12.9 percent) lends about $\$ 6,500$ million more to its domestic C\&I customers than a bank in the $25^{\text {th }}$ percentile (with a Tier 1 ratio of 8.6 percent) and also lends about $\$ 211$ million more to foreign customers. These differences represent more than 30 percent of the median bank's loans in each category. This evidence confirms that the internal liquidity management of a bank and, especially, its regulatory capital ratio are important economic determinants of differences across banks in lending in periods of liquidity stress.

\subsection{Bank-country-level regressions.}

Finally, we examine whether the dynamics of transmission internationally are better captured by specifications that contain breakdowns of data by foreign locations. The next set of results use 
locational data for each of the banks, with observations that cover claims by bank, by quarter, and by country location. The sample excludes banks with claims too small to qualify for locational reporting. Individual banks extend cross-border claims with up to 87 countries, with the median number of countries per bank equal to 27. The corresponding numbers of countries for extension of local claims are 57 and 7 respectively. In addition, we use data on internal liquidity management that is specific to each location. Specifically, we now use a measure of the amount of net borrowing by a foreign affiliate from the rest of the banking organization, as a fraction of the consolidated bank's assets. This net borrowing measure is different from that used in the specifications shown in Table 2. The former assesses net borrowing from the perspective of the head office of the banking organization, while the latter captures net borrowing from the perspective of the foreign affiliate.

Table 3 provides results for the effect of liquidity conditions on the growth of crossborder and foreign affiliates claims based on estimating equation (2). This specification permits bank business models to take into account the relative importance of countries as important investment locations or as important funding locations in adjusting lending and internal capital flows across foreign locations. The first three columns of Table 3 show that drivers of crosssectional differences in cross-border claims growth as liquidity risks rise include parent bank illiquid asset shares, core deposits, and net borrowing and lending within the organization. Banks with higher illiquid investment shares sustain their cross-border claims to core investment locations to a greater degree than to other locations. Banks with greater core deposit funding shares reduce growth in cross-border claims more than those banks with lower deposit funding shares. It is possibly the case that this occurs because the banks with higher core deposit shares are also the banks with a more pronounced focus on U.S. domestic lending as their core business activities.

We also observe that, conditional on higher liquidity risks, the growth in claims to a specific country is complementary to relatively higher net borrowing by (or lower net lending to) that location's foreign affiliate from the rest of the organization. However, the importance of these business model differences for cross-sectional differences in loan growth is less pronounced during the crisis period when central bank liquidity facilities are accessed. ${ }^{12}$

\footnotetext{
${ }^{12}$ As a robustness check, we have excluded Citigroup, which has activities in a large number of locations worldwide. The results are largely robust to this exclusion.
} 
Overall, however, it is important to recall that there is substantial time series and cross sectional variation in cross-border lending growth. The regression fit measures show that very little of the variation in cross-border lending growth is accounted for by the empirical specification, even with the inclusion of time-country fixed effects and differentiation across locations by their investment or funding status.

The last three columns of Table 3 report results for estimates of equation (2) using the bank-country-specific changes in foreign office claims as the dependent variable. Less than 20 percent of the time series and cross-sectional variation is explained by the regression specification. The liquidity risk proxies working through the balance sheet of the parent organization do not appear to be strong drivers of location-specific loan growth in affiliate locations. Banks appear to provide less credit through their foreign affiliates, in core funding locations, in periods of liquidity stress. However, is the ex ante differences across banks are not significant drivers of cross-sectional variation in lending during the period when banks accessed the Federal Reserve's liquidity facilities. In these same periods, parent banks that have more unused credit commitments and that fund themselves with more core deposits tend to sustain relatively more claims through their foreign affiliates. Overall, however, liquidity risk interacting with the balance sheet of the parent organization does not explain a large fraction of the substantial cross-sectional variation of cross-border claims or the claims booked by foreign affiliates.

\section{Concluding remarks}

This paper is part of a broader cross-country initiative to better understand the movement of international capital flows through banks. We have demonstrated that the global business model of some U.S. banks is associated with different drivers of cross-sectional variation in loan growth in response to changing liquidity risk conditions. Large U.S. banks without foreign affiliates have loan growth rates that differ cross-sectionally mainly in line with their reliance on core deposits in bank funding. Large U.S. global banks have loan growth rates that differ mainly in relation to their use of liquidity management within the broader organization. Those banks that tend to borrow more from affiliates also have more stable domestic lending and credit growth as liquidity risk conditions worsen. The degree to which these organizations adjust the 
borrowing and lending vis-à-vis affiliates is, in turn, influenced by the balance sheet composition of the parent organization.

During more extreme liquidity risk conditions and when banks access official liquidity facilities, different characteristics of banks matter for cross-sectional lending variation. Banks with higher Tier 1 capital have higher growth rates in domestic lending and credit and rely relatively less on borrowing from their affiliates. Use of official liquidity is associated with less growth in net borrowing from affiliates for those banks with more illiquid assets and fewer core deposits. This type of internal net borrowing and organizational liquidity management becomes less important for cross-sectional distinctions across banks in lending to domestic and foreign customers. Official sector liquidity support can be important for containing adverse liquidity risk effects on the real economy and transmission abroad.

\section{References}

Bech, Morten and Tara Rice. 2009. "Profits and Balance Sheet Developments at U.S. Commercial Banks in 2008," Federal Reserve Bulletin, vol. 95, pp. A57-97.

Bord, Vitaly and Joao Santos. 2014. "Banks' Liquidity and the Cost of Liquidity to Corporations". Journal of Money, Credit and Banking, Supplement to Vol. 46, No. 1 (February), 13-45.

Buch, Claudia M. and Linda Goldberg. 2014. "International Banking and Liquidity Risk Management: Lessons from Across Countries." manuscript, Federal Reserve Bank of New York.

Cetorelli, Nicola, and Linda Goldberg. 2012a. "Banking Globalization and Monetary Transmission," Journal of Finance, vol. 67:5, 1811-1843.

Cetorelli, Nicola, and Linda Goldberg. 2012b. "Follow the Money: Quantifying Domestic Effects of Foreign Bank Shocks in the Great Recession," American Economic Review, vol. 102:3, 213-18.

Cetorelli, Nicola, and Linda Goldberg. 2012c. "Liquidity management of U.S. Global Banks: Internal Capital Markets in the Great Recession," Journal of International Economics, vol. 88:2 299-311. 
Cornett, M.M., J.J. McNutt, P. Strahan, and H. Tehranian. 2011. "Liquidity Risk Management and Credit Supply in the Financial Crisis." Journal of Financial Economics, vol. 101, 297312.

Correa, Ricardo, Horacio Sapriza, and Andrei Zlate, 2012. "Liquidity Shocks, Dollar Funding Costs, and the Bank Lending Channel During the European Sovereign Crisis" Federal Reserve Board International Finance Discussion Papers 2012-1059 (November).

Drehmann, Mathias and Kleopatra Nikolau. 2010. "Funding Liquidity Risk: Definition and Measurement” BIS Working Paper no. 316 (July).

Khwaja, Asim I. and Atif Mian. 2008. "Tracing the Impact of Bank Liquidity Shocks: Evidence from an Emerging Market," American Economic Review 98(4), 1413-1442.

Schnabl, Philipp. 2012. "The International Transmission of Bank Liquidity Shocks: Evidence from and Emerging Market," Journal of Finance 67(3), 897-932. 
Table 1: Summary Statistics for Large U.S. Bank-holding Companies, 2006Q1 to 2012 Q4

Panel A reports summary statistics for growth in liquid assets, loans, credit, net due to (head office), and domestic and foreign C\&I lending as well as other firm characteristics and central bank facility use. The data are observed quarterly from 2006Q1-2012Q4. Panel B reports summary statistics for growth in foreign-office claims, cross-border claims, and net internal borrowing. Note: foreign-office claims are not available on an immediate counterparty basis prior to 2006Q1, so the data in Panel B are observed quarterly from 2006Q2 to 2012Q4. Beginning-of-quarter assets are used to standardize most of the growth variables in Panels A and B. Assets and commitments, together, are used to standardize growth in credit. The panel is restricted to bank holding companies with greater than $\$ 10$ billion in total assets (2012 prices) during its final quarter in the sample. To mitigate the effect of bank mergers on the dependent variables, banks are excluded in a particular quarter when asset growth exceeds $10 \%$. Firm characteristic data in Panel A come from the FR Y9-C and are aggregated to the highest domestic holding company. On a quarterly basis, banks are split into subgroups: banks with foreign affiliates and banks without foreign affiliates. Banks are judged to have a foreign affiliate if they report positive aggregate foreign-office claims in the FFIEC 009. Banks that report zero foreign-office claims or do not report the FFIEC 009 are considered not to have a foreign affiliate. In Panel A, the net due to (or due from) variable, reported in the FFIEC 031, measures from the perspective of a bank's head office total net internal lending (or borrowing) vis-à-vis all its related domestic and international offices. Given that the flows include domestic intra-bank lending, net due to observations are excluded for banks without foreign affiliates. In Panel B, the net due to (or due from) variable, reported in the FFIEC 009, measures from the perspective of a bank's foreign office total net internal lending (or borrowing) vis-à-vis all its related offices in other countries. Facility use is a dummy variable indicating whether or not a bank accessed the Federal Reserve's Discount Window and Term Auction Facility in a particular quarter. The underlying loan-level data on central bank facility use are available through Federal Reserve Board of Governors' website. In Panel B, international claims are consolidated into regional aggregates for smaller and static exposures. Exposures to a particular country are grouped into a regional aggregate if total cross-border claims are less than $\$ 2$ billion across all banks and quarters in the sample or growth in cross-border claims, at the bank level, is zero for greater than $30 \%$ of the observations in the sample for the particular country. Core investment reflects the ratio of a bank's total foreign claims in a particular country (foreign-office and cross-border) over their total foreign claims across all countries. Core funding is a ratio of locally-raised deposits over locallyraised deposits plus net due inflow in a particular country. Growth variables are winsorized at the $1^{\text {st }}$ and 99th percentiles. Note: In Panel B, the growth variables, originally reported in growth relative to assets (percent), have been multiplied by a factor of 1,000.

\begin{tabular}{|c|c|c|c|c|c|c|c|c|c|}
\hline \multirow[b]{2}{*}{ Variable } & \multicolumn{3}{|c|}{$\begin{array}{l}\text { All Banks } \\
(\mathrm{n}=95)\end{array}$} & \multicolumn{3}{|c|}{$\begin{array}{l}\text { With Foreign Affiliates } \\
\qquad(\mathrm{n}=27)\end{array}$} & \multicolumn{3}{|c|}{$\begin{array}{l}\text { Without Foreign } \\
\text { Affiliates }(n=73)\end{array}$} \\
\hline & Mean & Median & SD & Mean & Median & SD & Mean & Median & SD \\
\hline \multicolumn{10}{|c|}{ Panel A: Balance sheet data (for each bank $i$ and quarter $t$ ) } \\
\hline Observations & 1920 & & & 505 & & & 1415 & & \\
\hline \multicolumn{10}{|l|}{ Dependent Variables } \\
\hline$\Delta$ Credit/(Assets + Commitments) $(\%)$ & 0.39 & 0.49 & 2.56 & -0.03 & 0.18 & 2.73 & 0.54 & 0.55 & 2.48 \\
\hline$\Delta$ Domestic C\&I Loans/Assets (\%) & 0.17 & 0.10 & 0.74 & 0.12 & 0.09 & 0.74 & 0.18 & 0.11 & 0.74 \\
\hline$\Delta$ Foreign C\&I Loans/Assets (\%) & 0.01 & 0.00 & 0.10 & 0.02 & 0.00 & 0.17 & 0.00 & 0.00 & 0.06 \\
\hline$\Delta$ Cross-Border Claims/Assets (\%) & & & & 0.14 & 0.01 & 1.19 & & & \\
\hline$\Delta$ Foreign-Office Claims/Assets (\%) & & & & 0.18 & 0.01 & 0.90 & & & \\
\hline$\Delta$ Net Due To (Head Office)/Assets (\%) & & & & 0.06 & 0.00 & 1.54 & & & \\
\hline \multicolumn{10}{|l|}{ Independent Variables } \\
\hline Illiquid Assets/Assets (\%) & 72.86 & 78.15 & 16.13 & 66.28 & 75.32 & 18.28 & 75.20 & 78.75 & 14.60 \\
\hline Commitments Ratio (\%) & 21.82 & 20.53 & 11.69 & 27.40 & 27.48 & 10.90 & 19.82 & 19.02 & 11.32 \\
\hline Log Real Assets & 17.54 & 17.03 & 1.46 & 18.96 & 18.89 & 1.60 & 17.04 & 16.72 & 1.01 \\
\hline Core Deposits/Liabilities (\%) & 60.65 & 65.24 & 19.63 & 47.82 & 51.47 & 21.46 & 65.23 & 67.85 & 16.70 \\
\hline Tier1 Capital/RWA (\%) & 12.27 & 11.00 & 9.49 & 11.24 & 10.90 & 2.90 & 12.64 & 11.05 & 10.90 \\
\hline Net Due To (Head Office)/Liabilities (\%) & 5.78 & 3.56 & 8.62 & 5.78 & 3.56 & 8.62 & & & \\
\hline Facility Use & 0.17 & 0.00 & 0.37 & 0.19 & 0.00 & 0.39 & 0.16 & 0.00 & 0.37 \\
\hline \multicolumn{10}{|c|}{ Panel B: Locational data (for each bank $i$, quarter $t$, and country $j$ ). } \\
\hline & Mean & Median & SD & Obs. & Banks & Countries & & & \\
\hline$\Delta$ Cross Border Claims/Assets & 2.75 & 0.00 & 84.69 & 22171 & 41 & 87 & & & \\
\hline$\Delta$ Foreign Office Claims/Assets & 12.45 & 0.00 & 164.24 & 5911 & 27 & 57 & & & \\
\hline Core Investment Ratio (\%) & 2.76 & 0.23 & 8.86 & 22171 & 41 & 87 & & & \\
\hline Core Funding Ratio (\%) & 18.08 & 0.00 & 34.70 & 22171 & 41 & 87 & & & \\
\hline
\end{tabular}




\section{Table 2: Credit and Lending Effects of Liquidity Risk using Bank-Specific Data}

This table reports the effects of liquidity risk conditions, central bank facility use, and firm characteristics on growth in domestic and foreign C\&I lending and credit. Panels A and B respectively observe samples of banks without and with foreign affiliates, and Panel B includes additional regressions for changes in aggregate cross-border claims, foreign-office claims, and net due to (or net due from). The underlying fixed effects regressions are presented in Appendix 3. Results without fixed effects are presented in Appendix 4. Reported separately in each panel are the implied marginal effects for periods in which individual institutions used central bank liquidity facilities. The reported coefficients are the linear combination of the coefficients on the respective LIBOR-OIS and LIBOR-OIS*Facility interaction terms. Beginning-of-quarter assets are used to standardize growth in liquid assets, loans, and net due to, while assets and commitments, together, are used to standardize credit growth. The data are quarterly from 2006Q1 to 2012Q4 for a panel of bank holding companies. The panel is restricted to bank holding companies with greater than $\$ 10$ billion in total assets (2012 prices) during its final quarter in the sample. Banks are judged to have a foreign affiliate if they report positive aggregate foreign-office claims in the FFIEC 009. Banks that report zero foreign-office claims or do not report the FFIEC 009 are considered not to have a foreign affiliate. To mitigate the effect of bank mergers on the dependent variable, banks are excluded in a particular quarter when asset growth exceeds $10 \%$. Firm characteristic data comes from the FR Y9-C and are aggregated to the highest domestic holding company. The net due to (or due from) variable is reported in the FFIEC 031 and measures a bank's total net internal lending (or borrowing) vis-à-vis all its related domestic and international offices from the perspective of the head office. Given that the flows include domestic intra-bank lending, net due to observations are excluded for banks without foreign affiliates. Loan-level data on banks' borrowing through the Discount Window and Term Auction Facility are available through Federal Reserve Board of Governors' website. The LIBOR-OIS is the quarterly average of the daily difference between the London Interbank Offered Rate and the effective federal funds rate. Growth variables are winsorized at the 1st and 99th percentiles. All specifications include bank and time fixed effects. Standard errors are clustered by bank. ***,**, and * respectively indicate significance at the $1 \%, 5 \%$, and $10 \%$ level.

Panel A: Banks without Foreign Affiliates

\begin{tabular}{|c|c|c|c|}
\hline Variables & $\begin{array}{c}\Delta \text { Domestic } \\
\text { C\&I } \\
\text { Loans/Assets }\end{array}$ & $\begin{array}{c}\Delta \text { Foreign } \\
\text { C\&I } \\
\text { Loans/Assets }\end{array}$ & $\begin{array}{c}\Delta \text { Credit/ } \\
\text { (Assets }+ \\
\text { Commitments) }\end{array}$ \\
\hline Illiquid Assets & -0.006 & 0.000 & -0.012 \\
\hline Illiquid Assets*Libor-OIS & 0.000 & 0.000 & 0.020 \\
\hline Illiquid Assets*Libor-OIS * Facility & -0.004 & 0.000 & -0.018 \\
\hline Commitment Ratio & $0.023 * *$ & 0.000 & -0.051 \\
\hline Commitment Ratio*Libor-OIS & 0.010 & 0.001 & 0.012 \\
\hline Commitment Ratio*Libor-OIS*Facility & -0.007 & 0.000 & -0.014 \\
\hline Log Real Assets & -0.228 & 0.004 & $-2.199 * * *$ \\
\hline Log Real Assets*Libor-OIS & 0.032 & $-0.010 * *$ & 0.330 \\
\hline Log Real Assets*Libor-OIS * Facility & 0.022 & -0.002 & -0.114 \\
\hline Core Deposits & $-0.009 *$ & 0.000 & $-0.052 * * *$ \\
\hline Core Deposits*Libor-OIS & $0.007 * *$ & $-0.001 * * *$ & 0.007 \\
\hline Core Deposits*Libor-OIS*Facility & 0.000 & 0.000 & $0.051 * *$ \\
\hline Tier 1/RWA & 0.004 & 0.000 & 0.014 \\
\hline Tier 1/RWA*Libor-OIS & 0.003 & -0.001 & 0.016 \\
\hline Tier 1/RWA*Libor-OIS*Facility & -0.004 & 0.000 & 0.011 \\
\hline Observations & 1,415 & 1,415 & 1,415 \\
\hline R-squared & 0.18 & 0.05 & 0.20 \\
\hline Number of banks & 73 & 73 & 73 \\
\hline $\begin{array}{l}\text { Adjusted R-squared } \\
\text { Time Period }\end{array}$ & $\begin{array}{c}0.15 \\
\text { 2006Q1- } \\
\text { 2012Q4 }\end{array}$ & $\begin{array}{c}0.02 \\
\text { 2006Q1- } \\
\text { 2012Q4 }\end{array}$ & $\begin{array}{c}0.18 \\
\text { 2006Q1- } \\
\text { 2012Q4 }\end{array}$ \\
\hline Time fixed effects & Yes & Yes & Yes \\
\hline Bank fixed effects & Yes & Yes & Yes \\
\hline \multicolumn{4}{|l|}{ Central Bank Facility } \\
\hline Illiquid Assets & -0.005 & -0.001 & 0.002 \\
\hline Commitment Ratio & 0.003 & 0.000 & -0.002 \\
\hline Log Real Assets & 0.054 & $-0.012 * *$ & 0.216 \\
\hline Core Deposits & 0.006 & $-0.001 * * *$ & $0.058^{* *}$ \\
\hline Tier 1/RWA & -0.001 & -0.001 & 0.027 \\
\hline
\end{tabular}


Panel B: Banks with Foreign Affiliates

\begin{tabular}{|c|c|c|c|c|c|c|}
\hline Variables & $\begin{array}{l}\Delta \text { Domestic } \\
\text { C\&I } \\
\text { Loans/Assets }\end{array}$ & $\begin{array}{c}\Delta \text { Foreign } \\
\text { C\&I } \\
\text { Loans/Assets }\end{array}$ & $\begin{array}{c}\Delta \text { Credit/ } \\
\text { (Assets + } \\
\text { Commitments) }\end{array}$ & $\begin{array}{c}\Delta \text { Cross- } \\
\text { border } \\
\text { Claims/Assets } \\
\end{array}$ & $\begin{array}{c}\Delta \text { Foreign- } \\
\text { office } \\
\text { Claims/Assets }\end{array}$ & $\begin{array}{c}\Delta \text { Net Due To } \\
\text { (Head } \\
\text { Office)/ } \\
\text { Assets } \\
\end{array}$ \\
\hline Illiquid Assets & 0.009 & -0.002 & 0.009 & 0.009 & 0.022 & 0.023 \\
\hline Illiquid Assets*Libor-OIS & 0.013 & 0.007 & $0.102 *$ & $0.045^{* *}$ & 0.035 & -0.026 \\
\hline Illiquid Assets*Libor-OIS *Facility & -0.020 & $-0.007^{*}$ & -0.034 & $-0.040^{*}$ & -0.039 & $-0.087^{*}$ \\
\hline Commitment Ratio & -0.001 & -0.004 & -0.062 & 0.018 & -0.018 & 0.037 \\
\hline Commitment Ratio*Libor-OIS & -0.004 & 0.002 & -0.087 & $0.040 * *$ & 0.005 & $0.066^{*}$ \\
\hline Commitment Ratio*Libor-OIS*Facility & 0.005 & -0.005 & 0.052 & -0.014 & $-0.020 * *$ & -0.034 \\
\hline Log Real Assets & $-1.220 * * *$ & $-0.125 * *$ & $-4.200 * * *$ & 0.053 & $0.700^{* *}$ & $-1.090 * *$ \\
\hline Log Real Assets*Libor-OIS & $0.159 * *$ & -0.019 & $0.719^{*}$ & $-0.442 * * *$ & -0.185 & $-0.578^{*}$ \\
\hline Log Real Assets*Libor-OIS*Facility & -0.008 & 0.021 & -0.047 & 0.088 & 0.088 & $0.365 * *$ \\
\hline Core Deposits & 0.005 & 0.001 & -0.006 & 0.004 & $0.040 * *$ & -0.002 \\
\hline Core Deposits*Libor-OIS & 0.007 & -0.001 & -0.001 & -0.019 & -0.004 & 0.006 \\
\hline Core Deposits*Libor-OIS*Facility & 0.009 & 0.004 & -0.001 & 0.029 & 0.027 & $0.091 * *$ \\
\hline Tier 1/RWA & $-0.059^{*}$ & 0.004 & $-0.289 * *$ & $0.096^{*}$ & $0.123 * *$ & 0.060 \\
\hline Tier 1/RWA*Libor-OIS & -0.002 & -0.018 & 0.250 & -0.148 & -0.110 & -0.248 \\
\hline Tier 1/RWA*Libor-OIS*Facility & $0.104 *$ & 0.022 & 0.135 & 0.031 & 0.064 & $-0.270 * * *$ \\
\hline Net Due To (Head Office) & -0.015 & -0.004 & 0.028 & -0.010 & 0.034 & $-0.221 * * *$ \\
\hline Net Due To (Head Office)*Libor-OIS & $0.045^{* * *}$ & $0.010^{* * *}$ & $0.166^{* * *}$ & $0.059 * * *$ & 0.005 & 0.034 \\
\hline Net Due To (Head Office)*Libor-OIS*Facility & $-0.035 * *$ & $-0.008^{*}$ & $-0.130 * *$ & 0.014 & 0.007 & -0.082 \\
\hline Observations & 505 & 505 & 505 & 502 & 483 & 505 \\
\hline R-squared & 0.46 & 0.16 & 0.44 & 0.16 & 0.20 & 0.30 \\
\hline Number of banks & 27 & 27 & 27 & 27 & 27 & 27 \\
\hline $\begin{array}{l}\text { Adjusted R-squared } \\
\text { Time Period }\end{array}$ & $\begin{array}{c}0.40 \\
\text { 2006Q1- } \\
\text { 2012Q4 }\end{array}$ & $\begin{array}{c}0.07 \\
\text { 2006Q1- } \\
\text { 2012Q4 }\end{array}$ & $\begin{array}{c}0.38 \\
\text { 2006Q1- } \\
\text { 2012Q4 }\end{array}$ & $\begin{array}{c}0.08 \\
\text { 2006Q1- } \\
\text { 2012Q4 }\end{array}$ & $\begin{array}{c}0.12 \\
\text { 2006Q2- } \\
\text { 2012Q4 }\end{array}$ & $\begin{array}{c}0.23 \\
\text { 2006Q1- } \\
\text { 2012Q4 }\end{array}$ \\
\hline Time fixed effects & Yes & Yes & Yes & Yes & Yes & Yes \\
\hline Bank fixed effects & Yes & Yes & Yes & Yes & Yes & Yes \\
\hline \multicolumn{7}{|l|}{ Central Bank Facility Use } \\
\hline Illiquid Assets & -0.007 & 0.000 & $0.068 * *$ & 0.005 & -0.005 & $-0.112 * * *$ \\
\hline Commitment Ratio & 0.000 & -0.003 & -0.034 & $0.026^{* *}$ & -0.015 & 0.032 \\
\hline Log Real Assets & $0.151 * *$ & 0.002 & $0.672 *$ & $-0.354 * * *$ & -0.097 & -0.213 \\
\hline Core Deposits & 0.016 & 0.003 & -0.003 & 0.010 & 0.023 & $0.097 * * *$ \\
\hline Tier 1/RWA & $0.102 * * *$ & 0.003 & $0.385^{*}$ & -0.118 & -0.046 & $-0.518 * * *$ \\
\hline Net Due To (Head Office) & 0.010 & 0.002 & 0.036 & $0.073 * * *$ & 0.012 & -0.048 \\
\hline
\end{tabular}




\section{Table 3: International Claims and Liquidity Risk, using Bank-Location-Specific Data}

This table reports the marginal effects, as liquidity conditions worsen, of firm characteristics and central bank credit facility use on growth in country-specific cross-border and foreign-office claims. The underlying fixed effects regressions are presented in Appendix 5. For each firm characteristic variable and corresponding interactions with Core Funding and Core Investment, the No Use, Use, and Difference columns respectively represent, from the underlying regressions, the coefficient on the LIBOR-OIS interaction terms, the linear combination of the coefficients on the LIBOR-OIS and LIBOR-OIS*Facility interaction terms, and the difference between the two. Beginning-of-quarter assets are used to standardize growth in the dependent variables. Cross-border and foreign-office claims are measured on an immediate counterparty basis. The data are observed quarterly from 2006Q2 to 2012Q4 for a panel of U.S. bank holding companies. The panel is restricted to bank-holding companies with greater than $\$ 10$ billion in total assets (2012 prices) during its final quarter in the sample. For growth in foreign-office claims, the sample excludes observations when country-specific foreign-office claims are zero in both the current and previous quarter. To mitigate the effect of bank mergers on the dependent variables, banks are excluded in quarters when asset growth exceeds $10 \%$. Firm characteristic data comes from the FR Y9-C and are aggregated to the highest domestic holding company. Data on country-specific bank exposures are from the FFIEC 009. The net due to (or due from) variable measures a bank's total net internal lending (or borrowing) vis-à-vis all its related offices in other countries. Reported in the FFIEC 009, these flows reflect the perspective of the foreign office. International claims are consolidated into regional aggregates for smaller and static exposures. Exposures to a particular country are grouped into a regional aggregate if total cross-border claims are less than $\$ 2$ billion across all banks and quarters in the sample or there is zero growth in cross-border claims, at the bank level, for greater than $30 \%$ of the observations in the sample for the particular country. Exposures to Caribbean countries are also excluded. Loan-level data on banks' borrowing through the Discount Window and Term Auction Facility are available through Federal Reserve Board of Governors' website. The LIBOR-OIS is the quarterly average of the daily difference between the London Interbank Offered Rate and the effective federal funds rate. Growth variables are winsorized at the 1st and 99th percentiles. All specifications include country-time and bank fixed effects. Standard errors are clustered by bank. ***,**, and * respectively indicate significance at the $1 \%, 5 \%$, and $10 \%$ level. The dependent variables, originally reported in growth relative to assets (percent), have been multiplied by a factor of 1,000 .

\begin{tabular}{|c|c|c|c|c|c|c|}
\hline \multirow[b]{2}{*}{ Central Bank Facility Access: } & \multicolumn{3}{|c|}{$\Delta$ Cross-border Claims/Assets } & \multicolumn{3}{|c|}{$\Delta$ Foreign-office Claims/Assets } \\
\hline & No Use & Use & Difference & No Use & Use & Difference \\
\hline Illiquid Assets & $0.508^{* * *}$ & $0.565^{* * *}$ & 0.057 & -0.640 & -2.792 & -2.152 \\
\hline Illiquid Assets*CF & -0.465 & $-1.001 * * *$ & -0.536 & -0.559 & 1.211 & 1.770 \\
\hline Illiquid Assets*CI & $10.136^{* * *}$ & 2.545 & -7.591 & 7.465 & -9.267 & $-16.732 *$ \\
\hline Commitment Ratio & 0.330 & $0.397 * *$ & 0.067 & 2.666 & $4.317 * *$ & 1.651 \\
\hline Commitment Ratio*CF & 0.691 & 0.094 & -0.596 & 2.742 & -1.656 & $-4.398 *$ \\
\hline Commitment Ratio*CI & -1.334 & $5.696 * *$ & $7.030^{* *}$ & -3.474 & -23.445 & -19.971 \\
\hline Log Real Assets & $-4.603^{* *}$ & $-3.785^{*}$ & 0.818 & -20.571 & -22.799 & -2.228 \\
\hline Log Real Assets*CF & -1.043 & -0.587 & 0.456 & -3.040 & -2.250 & 0.791 \\
\hline Log Real Assets*CI & $-20.918 * * *$ & -15.692 & 5.226 & -20.404 & 46.469 & 66.873 \\
\hline Core Deposits & -0.193 & $-0.473 * *$ & -0.281 & 1.253 & $3.273^{*}$ & 2.020 \\
\hline Core Deposits*CF & 0.877 & $1.152 * * *$ & 0.275 & -0.296 & -0.409 & -0.113 \\
\hline Core Deposits*CI & $-6.050 * * *$ & 1.360 & $7.411 * *$ & 1.068 & 13.453 & 12.385 \\
\hline Tier 1 Capital & -0.915 & $-1.931 * *$ & -1.016 & -6.376 & -1.973 & 4.403 \\
\hline Tier 1 Capital*CF & -0.134 & 1.570 & 1.704 & -4.220 & 4.045 & 8.266 \\
\hline Tier 1 Capital*CI & -12.443 & -19.281 & -6.838 & -17.869 & -42.041 & -24.172 \\
\hline Net Due To (Foreign Office) & 2.258 & $35.622 * * *$ & $33.364 * *$ & 49.699 & 6.364 & -43.335 \\
\hline Net Due To (Foreign Office)*CF & $-26.295^{*}$ & $-37.976 * * *$ & -11.681 & $-59.945^{*}$ & -5.108 & 54.836 \\
\hline Net Due To (Foreign Office)*CI & $58.862 * * *$ & $-67.519 * *$ & $-126.380 * * *$ & -81.810 & 46.717 & 128.528 \\
\hline Observations & 22,171 & & & 5,911 & & \\
\hline R-squared & 0.10 & & & 0.19 & & \\
\hline Number of banks & 41 & & & 27 & & \\
\hline Bank fixed effects & Yes & & & Yes & & \\
\hline Country-time fixed effects & Yes & & & Yes & & \\
\hline
\end{tabular}




\title{
Appendix to
}

\section{Liquidity Risk and U.S. Bank Lending at Home and Abroad}

U.S. Contribution to the

2013 International Banking Research Network (IBRN)

\author{
Ricardo Correa \\ Federal Reserve Board \\ Ricardo.Correa@frb.gov \\ Linda Goldberg \\ Linda.Goldberg@,ny.frb.org \\ Tara Rice \\ Federal Reserve Board \\ Tara.N.Rice@,frb.gov
}

Federal Reserve Bank of New York and NBER 


\section{Appendix 1: Construction of variables}

\begin{tabular}{|c|c|c|c|}
\hline Variable Name & Report Form Description & Source & Notes \\
\hline \multicolumn{4}{|l|}{ Dependent Variables } \\
\hline $\begin{array}{l}\Delta \text { Credit/(Assets }+ \\
\text { Commitments) })_{(t-1)}\end{array}$ & $\begin{array}{l}\Delta \text { (All unused commitments }+ \text { Loans and leases held } \\
\text { for sale + Loans and leases, net of unearned income } \\
\text { and allowance for loan and lease losses) / (Assets }+ \\
\text { All unused commitments) }\end{array}$ & FR Y9-C & \\
\hline $\begin{array}{l}\Delta \text { Domestic C\&I } \\
\text { Loans/Assets }(\mathrm{t}-1)\end{array}$ & $\Delta$ Domestic C\&I loans/Assets & FR Y9-C & \\
\hline $\begin{array}{l}\Delta \text { Foreign C\&I } \\
\text { Loans/Assets }(t-1)\end{array}$ & $\Delta$ Foreign C\&I Loans/Assets & FR Y9-C & \\
\hline $\begin{array}{l}\Delta \text { Cross-Border } \\
\text { Claims/Assets }(\mathrm{t}-1)\end{array}$ & $\begin{array}{l}\Delta \text { (Cross-border claims on banks, public, and other) } \\
\text { /Assets }\end{array}$ & $\begin{array}{l}\text { FFIEC 009, } \\
\text { FR Y9-C }\end{array}$ & $\begin{array}{l}\text { Cross-border claims are evaluated } \\
\text { on an immediate counterparty basis }\end{array}$ \\
\hline $\begin{array}{l}\Delta \text { Foreign-Office } \\
\text { Claims/Assets }(t-1)\end{array}$ & $\begin{array}{l}\Delta[\text { (Foreign-office claims on local residents in non- } \\
\text { local currency: banks, public, and other) }+ \text { (Foreign- } \\
\text { office claims on local residents in local currency) }] \\
\text { /Assets }\end{array}$ & $\begin{array}{l}\text { FFIEC 009, } \\
\text { FR Y9-C }\end{array}$ & $\begin{array}{l}\text { Foreign-office claims are evaluated } \\
\text { on an immediate counterparty basis }\end{array}$ \\
\hline $\begin{array}{l}\Delta \text { Net Due To (Foreign } \\
\text { Office)/Assets } \\
(\mathrm{t}-1)\end{array}$ & $\begin{array}{l}\Delta \text { (Net due to (or due from) own related offices in } \\
\text { other countries)/Assets }\end{array}$ & $\begin{array}{l}\text { FFIEC 031, } \\
\text { FR Y9-C }\end{array}$ & $\begin{array}{l}\text { From the perspective of the foreign } \\
\text { office vis-a-vis other foreign } \\
\text { offices in other countries. }\end{array}$ \\
\hline \multicolumn{4}{|c|}{ Independent Variables } \\
\hline $\begin{array}{l}\text { Illiquid } \operatorname{Assets}_{(\mathrm{t}-1)} / \\
\text { Assets }_{(\mathrm{t}-1)}\end{array}$ & $\begin{array}{l}\text { [Loans held for sale + Loans net of unearned income } \\
\text { and allowances for loan \& lease losses (A.L.L.) }+ \\
\text { Held-to-maturity MBS, ABS, and structured } \\
\text { financial products (amortized cost) + Available-for- } \\
\text { sale MBS, ABS, and structured financial products } \\
\text { (fair value)]/Assets }\end{array}$ & FR Y9-C & $\begin{array}{l}\text { Structured financial products } \\
\text { available on the FR Y9-C report } \\
\text { form starting } 2009 \text { Q2. }\end{array}$ \\
\hline Commitments Ratio $_{(t-1)}$ & $\begin{array}{l}\text { All unused commitments / (Assets + All unused } \\
\text { commitments ) }\end{array}$ & FR Y9-C & \\
\hline Log Real Assets $(\mathrm{t-1)}$ & $\log$ (Total assets) & FR Y9-C & \\
\hline $\begin{array}{l}\text { Core Deposits }_{(t-1)} / \\
\text { Liabilities }_{(t-1)}\end{array}$ & $\begin{array}{l}\text { [Total transaction accounts + Savings deposits } \\
\text { (MMDAs, etc.) + Total time deposit accounts with } \\
\text { balances less than } \$ 100,000] / \text { Liabilities }\end{array}$ & FR Y9-C & \\
\hline $\begin{array}{l}\text { Tier 1 Capital }_{(\mathrm{t}-1)} / \\
\text { RWA }_{(\mathrm{t}-1)}\end{array}$ & Tier 1 capital/Risk-weighted assets & FR Y9-C & \\
\hline 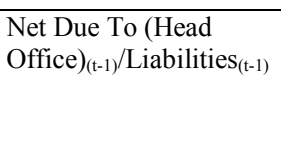 & $\begin{array}{l}\text { (Net due to own foreign offices - Net due from own } \\
\text { foreign offices)/Total liabilities }\end{array}$ & $\begin{array}{l}\text { FFIEC 031, } \\
\text { FR Y9-C }\end{array}$ & $\begin{array}{l}\text { From the perspective of the head } \\
\text { office vis-a-vis own foreign offices, } \\
\text { edge and agreement subsidiaries, } \\
\text { and IBFs. }\end{array}$ \\
\hline $\begin{array}{l}\text { Core Investment } \\
\text { Ratio }_{(t-1)}\end{array}$ & $\begin{array}{l}\text { [Cross-border claims + Foreign-office claims] / } \\
\text { [Aggregate cross-border claims + Aggregate foreign- } \\
\text { office claims] }\end{array}$ & FFIEC 009 & \\
\hline Core Funding Ratio $(\mathrm{t}-1)$ & Local liabilities/(Local liabilities + Net due inflow) & FFIEC 009 & $\begin{array}{l}\text { Net due inflow includes only } \\
\text { positive values of fcex } 8595 \text {. Net } \\
\text { due inflow is evaluated from the } \\
\text { perspective of foreign office vis-a- } \\
\text { vis other foreign offices in other } \\
\text { countries. }\end{array}$ \\
\hline
\end{tabular}




\section{Appendix 2: Non-winsorized Summary Statistics for Large U.S. Banks, 2006Q1 to 2012Q4}

Contrary to Table 1 , this table reports the growth variables prior to winsorization $\left(1^{\text {st }}\right.$ and $99^{\text {th }}$ percentiles $)$ and does not exclude from the sample bank observations in quarters when asset growth exceeds ten percent. Panel A reports summary statistics for growth in liquid assets, loans, credit, net due to (head office), and domestic and foreign C\&I lending as well as other firm characteristics and central bank facility use. The data are observed quarterly from 2006Q1-2012Q4. Panel B reports summary statistics for growth in foreign-office claims, cross-border claims, and net internal borrowing. Note: foreign-office claims are not available on an immediate counterparty basis prior to 2006Q1, so the data in Panel B are observed quarterly from 2006Q2 to 2012Q4. Beginning-of-quarter assets are used to standardize most of the growth variables in Panels A and B. Assets and commitments, together, are used to standardize growth in credit. The panel is restricted to bank holding companies with greater than $\$ 10$ billion in total assets (2012 prices) during its final quarter in the sample. Firm characteristic data in Panel A come from the FR Y9-C and are aggregated to the highest domestic holding company. On a quarterly basis, banks are split into subgroups: banks with foreign affiliates and banks without foreign affiliates. Banks are judged to have a foreign affiliate if they report positive aggregate foreign-office claims in the FFIEC 009. Banks that report zero foreign-office claims or do not report the FFIEC 009 are considered not to have a foreign affiliate. In Panel A, the net due to (or due from) variable, reported in the FFIEC 031, measures from the perspective of a bank's head office total net internal lending (or borrowing) vis-à-vis all its related domestic and international offices. Given that the flows include domestic intra-bank lending, net due to observations are excluded for banks without foreign affiliates. In Panel B, the net due to (or due from) variable, reported in the FFIEC 009, measures from the perspective of a bank's foreign office total net internal lending (or borrowing) vis-à-vis all its related offices in other countries. Facility use is a dummy variable indicating whether or not a bank accessed the Federal Reserve's Discount Window and Term Auction Facility in a particular quarter. The underlying loan-level data on central bank facility use are available through Federal Reserve Board of Governors' website. In Panel B, international claims are consolidated into regional aggregates for smaller and static exposures. Exposures to a particular country are grouped into a regional aggregate if total cross-border claims are less than $\$ 2$ billion across all banks and quarters in the sample or growth in cross-border claims, at the bank level, is zero for greater than $30 \%$ of the observations in the sample for the particular country. Core Investment reflects the ratio of a bank's total foreign claims in a particular country (foreign-office and cross-border) over their total foreign claims across all countries. Core Funding is a ratio of locally-raised deposits over locally-raised deposits plus net due inflow in a particular country. Note: In Panel B, the growth variables, originally reported in growth relative to assets (percent), have been multiplied by a factor of 1,000 .

\begin{tabular}{|c|c|c|c|c|c|c|c|c|c|}
\hline \multirow[b]{2}{*}{ Variable } & \multicolumn{3}{|c|}{$\begin{array}{l}\text { All Banks } \\
(\mathrm{n}=95)\end{array}$} & \multicolumn{3}{|c|}{$\begin{array}{l}\text { With Foreign Affiliates } \\
\qquad(\mathrm{n}=27)\end{array}$} & \multicolumn{3}{|c|}{$\begin{array}{r}\text { Without Foreign } \\
\text { Affiliates }(\mathrm{n}=73)\end{array}$} \\
\hline & Mean & Median & SD & Mean & Median & SD & Mean & Median & SD \\
\hline \multicolumn{10}{|c|}{ Panel A: Balance sheet data (for each bank $i$ and quarter $t$ ) } \\
\hline Observations & 1984 & & & 526 & & & 1458 & & \\
\hline \multicolumn{10}{|l|}{ Dependent Variables } \\
\hline$\Delta$ Credit/(Assets + Commitments) $(\%)$ & 1.08 & 0.58 & 10.03 & 0.14 & 0.33 & 6.96 & 1.41 & 0.66 & 10.88 \\
\hline$\Delta$ Domestic C\&I Loans/Assets (\%) & 0.32 & 0.11 & 2.31 & 0.18 & 0.09 & 1.47 & 0.37 & 0.12 & 2.54 \\
\hline$\Delta$ Foreign C\&I Loans/Assets ( $\%)$ & 0.02 & 0.00 & 0.46 & 0.01 & 0.00 & 0.39 & 0.02 & 0.00 & 0.48 \\
\hline$\Delta$ Cross-Border Claims/Assets (\%) & & & & 0.19 & 0.01 & 1.41 & & & \\
\hline$\Delta$ Foreign-Office Claims/Assets (\%) & & & & 0.18 & 0.02 & 1.45 & & & \\
\hline$\Delta$ Net Due To (Head Office)/Assets (\%) & & & & 0.08 & 0.02 & 2.03 & & & \\
\hline \multicolumn{10}{|l|}{ Independent Variables } \\
\hline Illiquid Assets/Assets (\%) & 72.52 & 78.12 & 16.63 & 66.15 & 74.92 & 18.27 & 74.75 & 78.72 & 15.40 \\
\hline Commitments Ratio (\%) & 21.77 & 20.41 & 11.76 & 27.49 & 27.47 & 11.02 & 19.76 & 18.95 & 11.34 \\
\hline Log Real Assets & 17.53 & 17.02 & 1.47 & 18.96 & 18.89 & 1.58 & 17.03 & 16.70 & 1.03 \\
\hline Core Deposits/Liabilities (\%) & 60.41 & 65.28 & 20.01 & 47.46 & 50.85 & 21.60 & 64.95 & 67.91 & 17.27 \\
\hline Tierl Capital/RWA (\%) & 12.26 & 11.01 & 9.34 & 11.25 & 10.89 & 2.92 & 12.61 & 11.06 & 10.70 \\
\hline Net Due To (Head Office)/Liabilities (\%) & & & & 5.96 & 3.69 & 8.86 & . & . & . \\
\hline Facility Use & 0.17 & 0.00 & 0.37 & 0.19 & 0.00 & 0.39 & 0.16 & 0.00 & 0.37 \\
\hline \multicolumn{10}{|c|}{ Panel B: Locational data (for each bank $i$, quarter $t$, and country $j$ ) } \\
\hline & Mean & Median & SD & Obs. & Banks & Countries & & & \\
\hline$\Delta$ Cross Border Claims/Assets (\%) & 5.58 & 0.00 & 227.54 & 23622 & 46 & 87 & & & \\
\hline$\Delta$ Foreign Office Claims/Assets (\%) & 15.98 & 0.04 & 390.98 & 6281 & 30 & 58 & & & \\
\hline Core Investment Ratio (\%) & 2.76 & 0.23 & 8.88 & 23622 & 46 & 87 & & & \\
\hline Core Funding Ratio (\%) & 17.86 & 0.00 & 34.57 & 23622 & 46 & 87 & & & \\
\hline
\end{tabular}




\section{Appendix 3: Underlying Regressions for Credit and Lending Effects of Liquidity Risk}

The coefficients reported reflect the underlying results for Table 2. This table reports the effects of liquidity risk conditions, central bank facility use, and firm characteristics on growth in domestic and foreign C\&I lending and credit. Panels A and B (from Table 2) respectively observe samples of banks without and with foreign affiliates, and Panel B includes additional regressions for changes in aggregate cross-border claims, foreign-office claims, and net due to (or net due from). Beginning-of-quarter assets are used to standardize growth in liquid assets, loans, and net due to, while assets and commitments, together, are used to standardize credit growth. The data are observed quarterly from 2006Q1 to 2012Q4 for a panel of bank holding companies. The panel is restricted to bank holding companies with greater than $\$ 10$ billion in total assets (2012 prices) during its final quarter in the sample. Banks are judged to have a foreign affiliate if they report positive aggregate foreign-office claims in the FFIEC 009. Banks that report zero foreign-office claims or do not report the FFIEC 009 are considered not to have a foreign affiliate. To mitigate the effect of bank mergers on the dependent variable, banks are excluded in a particular quarter when asset growth exceeds 10\%. Firm characteristic data comes from the FR Y9-C and are aggregated to the highest domestic holding company. The net due to (or due from) variable is reported in the FFIEC 031 and measures a bank's total net internal lending (or borrowing) vis-à-vis all its related domestic and international offices from the perspective of the head office. Given that the flows include domestic intra-bank lending, net due to observations are excluded for banks without foreign affiliates. Loan-level data on banks' borrowing through the Discount Window and Term Auction Facility are available through Federal Reserve Board of Governors' website. The LIBOR-OIS is the quarterly average of the daily difference between the London Interbank Offered Rate and the effective federal funds rate. Growth variables are winsorized at the 1st and 99th percentiles. All specifications include bank and time fixed effects. Standard errors are clustered by bank. ${ }^{* *}, * *$, and * respectively indicate significance at the $1 \%, 5 \%$, and $10 \%$ level.

\begin{tabular}{|c|c|c|c|c|c|c|c|c|c|}
\hline VARIABLES & $\begin{array}{c}(1) \\
\Delta \text { Domestic } \\
\text { C\&I Loans/ } \\
\text { Assets } \\
\end{array}$ & $\begin{array}{c}\text { (2) } \\
\Delta \text { Foreign } \\
\text { C\&I Loans/ } \\
\text { Assets } \\
\end{array}$ & $\begin{array}{c}(3) \\
\Delta \text { Credit/ } \\
\text { (Commitments } \\
+ \text { Assets) }\end{array}$ & $\begin{array}{c}\text { (4) } \\
\Delta \text { Domestic } \\
\text { C\&I Loans/ } \\
\text { Assets } \\
\end{array}$ & $\begin{array}{c}(5) \\
\Delta \text { Foreign } \\
\text { C\&I Loans/ } \\
\text { Assets } \\
\end{array}$ & $\begin{array}{c}(6) \\
\Delta \text { Credit/ } \\
\text { (Commitments } \\
+ \text { Assets) }\end{array}$ & $\begin{array}{c}(7) \\
\Delta \text { Cross- } \\
\text { border } \\
\text { Claims/ } \\
\text { Assets } \\
\end{array}$ & $\begin{array}{c}(8) \\
\Delta \text { Foreign- } \\
\text { office } \\
\text { Claims/ } \\
\text { Assets } \\
\end{array}$ & $\begin{array}{c}(9) \\
\Delta \text { Net Due } \\
\text { To (Head } \\
\text { Office)/ } \\
\text { Assets } \\
\end{array}$ \\
\hline Illiquid Assets $_{(t-1)} / \operatorname{Assets}_{(t-1)}$ & $\begin{array}{c}-0.006 \\
{[0.008]}\end{array}$ & $\begin{array}{c}0.000 \\
{[0.000]}\end{array}$ & $\begin{array}{l}-0.012 \\
{[0.019]}\end{array}$ & $\begin{array}{c}0.009 \\
{[0.011]}\end{array}$ & $\begin{array}{l}-0.002 \\
{[0.003]}\end{array}$ & $\begin{array}{c}0.009 \\
{[0.031]}\end{array}$ & $\begin{array}{c}0.009 \\
{[0.016]}\end{array}$ & $\begin{array}{c}0.022 \\
{[0.018]}\end{array}$ & $\begin{array}{c}0.023 \\
{[0.027]}\end{array}$ \\
\hline Illiquid Assets $_{(\mathrm{t}-1)} /$ Assets $_{(\mathrm{t}-1)} *$ Libor-OIS & $\begin{array}{c}-0.000 \\
{[0.003]}\end{array}$ & $\begin{array}{c}-0.000 \\
{[0.001]}\end{array}$ & $\begin{array}{c}0.020 \\
{[0.013]}\end{array}$ & $\begin{array}{c}0.013 \\
{[0.010]}\end{array}$ & $\begin{array}{c}0.007 \\
{[0.004]}\end{array}$ & $\begin{array}{l}0.102 * \\
{[0.055]}\end{array}$ & $\begin{array}{l}0.045^{* *} \\
{[0.022]}\end{array}$ & $\begin{array}{c}0.035 \\
{[0.025]}\end{array}$ & $\begin{array}{c}-0.026 \\
{[0.047]}\end{array}$ \\
\hline 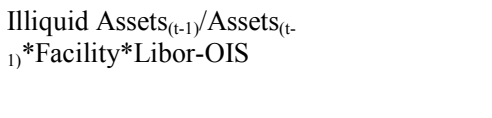 & $\begin{array}{c}-0.004 \\
{[0.007]}\end{array}$ & $\begin{array}{l}-0.000 \\
{[0.000]}\end{array}$ & $\begin{array}{l}-0.018 \\
{[0.036]}\end{array}$ & $\begin{array}{c}-0.020 \\
{[0.014]}\end{array}$ & $\begin{array}{c}-0.007 * \\
{[0.004]}\end{array}$ & $\begin{array}{c}-0.034 \\
{[0.044]}\end{array}$ & $\begin{array}{l}-0.040 * \\
{[0.022]}\end{array}$ & $\begin{array}{l}-0.039 \\
{[0.025]}\end{array}$ & $\begin{array}{r}-0.087^{*} \\
{[0.049]}\end{array}$ \\
\hline Commitment Ratio $_{(t-1)}$ & $\begin{array}{c}0.023^{* *} \\
{[0.010]}\end{array}$ & $\begin{array}{c}-0.000 \\
{[0.001]}\end{array}$ & $\begin{array}{c}-0.051 \\
{[0.035]}\end{array}$ & $\begin{array}{c}-0.001 \\
{[0.009]}\end{array}$ & $\begin{array}{c}-0.004 \\
{[0.004]}\end{array}$ & $\begin{array}{c}-0.062 \\
{[0.062]}\end{array}$ & $\begin{array}{c}0.018 \\
{[0.021]}\end{array}$ & $\begin{array}{c}-0.018 \\
{[0.011]}\end{array}$ & $\begin{array}{c}0.037 \\
{[0.024]}\end{array}$ \\
\hline Commitment Ratio(t-1) $*$ Libor-OIS & $\begin{array}{c}0.010 \\
{[0.006]}\end{array}$ & $\begin{array}{c}0.001 \\
{[0.000]}\end{array}$ & $\begin{array}{c}0.012 \\
{[0.026]}\end{array}$ & $\begin{array}{c}-0.004 \\
{[0.008]}\end{array}$ & $\begin{array}{c}0.002 \\
{[0.003]}\end{array}$ & $\begin{array}{c}-0.087 \\
{[0.053]}\end{array}$ & $\begin{array}{c}0.040^{* *} \\
{[0.016]}\end{array}$ & $\begin{array}{c}0.005 \\
{[0.016]}\end{array}$ & $\begin{array}{l}0.066^{*} \\
{[0.037]}\end{array}$ \\
\hline Commitment Ratio $_{(\mathrm{t}-1)} *$ Facility*Libor-OIS & $\begin{array}{c}-0.007 \\
{[0.007]}\end{array}$ & $\begin{array}{l}-0.000 \\
{[0.000]}\end{array}$ & $\begin{array}{l}-0.014 \\
{[0.031]}\end{array}$ & $\begin{array}{c}0.005 \\
{[0.007]}\end{array}$ & $\begin{array}{l}-0.005 \\
{[0.004]}\end{array}$ & $\begin{array}{c}0.052 \\
{[0.043]}\end{array}$ & $\begin{array}{l}-0.014 \\
{[0.016]}\end{array}$ & $\begin{array}{c}-0.020 * * \\
{[0.010]}\end{array}$ & $\begin{array}{c}-0.034 \\
{[0.022]}\end{array}$ \\
\hline Log Real Assets(t-1) & $\begin{array}{c}-0.228 \\
{[0.171]}\end{array}$ & $\begin{array}{c}0.004 \\
{[0.013]}\end{array}$ & $\begin{array}{c}-2.199 * * * \\
{[0.809]}\end{array}$ & $\begin{array}{c}-1.220 * * * \\
{[0.242]}\end{array}$ & $\begin{array}{c}-0.125^{* *} \\
{[0.052]}\end{array}$ & $\begin{array}{c}-4.200 * * * \\
{[1.263]}\end{array}$ & $\begin{array}{c}0.053 \\
{[0.268]}\end{array}$ & $\begin{array}{c}0.700 * * \\
{[0.289]}\end{array}$ & $\begin{array}{c}-1.090 * * \\
{[0.456]}\end{array}$ \\
\hline Log Real Assets $_{(\mathrm{t}-1)} *$ Libor-OIS & $\begin{array}{c}0.032 \\
{[0.053]}\end{array}$ & $\begin{array}{c}-0.010^{* *} \\
{[0.004]}\end{array}$ & $\begin{array}{c}0.330 \\
{[0.226]}\end{array}$ & $\begin{array}{c}0.159^{* *} \\
{[0.067]}\end{array}$ & $\begin{array}{c}-0.019 \\
{[0.038]}\end{array}$ & $\begin{array}{l}0.719^{*} \\
{[0.367]}\end{array}$ & $\begin{array}{c}-0.442 * * * \\
{[0.129]}\end{array}$ & $\begin{array}{c}-0.185 \\
{[0.163]}\end{array}$ & $\begin{array}{l}-0.578^{*} \\
{[0.333]}\end{array}$ \\
\hline $\log _{\text {Real Assets }(\mathrm{t}-1)} *$ Facility*Libor-OIS & 0.022 & -0.002 & -0.114 & -0.008 & 0.021 & -0.047 & 0.088 & 0.088 & $0.365^{* *}$ \\
\hline
\end{tabular}




\begin{tabular}{|c|c|c|c|c|c|c|c|c|c|}
\hline & {$[0.035]$} & {$[0.002]$} & {$[0.177]$} & {$[0.034]$} & {$[0.015]$} & {$[0.157]$} & {$[0.097]$} & {$[0.069]$} & {$[0.137]$} \\
\hline \multirow[t]{2}{*}{ Core Deposits $_{(\mathrm{t}-1)} /$ Liabilities $_{(\mathrm{t}-1)}$} & $-0.009 *$ & 0.000 & $-0.052 * * *$ & 0.005 & 0.001 & -0.006 & 0.004 & $0.040 * *$ & -0.002 \\
\hline & {$[0.005]$} & {$[0.000]$} & {$[0.020]$} & {$[0.014]$} & {$[0.002]$} & {$[0.032]$} & {$[0.010]$} & {$[0.018]$} & {$[0.022]$} \\
\hline \multirow[t]{2}{*}{ Core Deposits $_{(\mathrm{t}-1)} /$ Liabilities $_{(\mathrm{t}-1)} *$ Libor-OIS } & $0.007 * *$ & $-0.001 * * *$ & 0.007 & 0.007 & -0.001 & -0.001 & -0.019 & -0.004 & 0.006 \\
\hline & {$[0.003]$} & {$[0.000]$} & {$[0.013]$} & {$[0.007]$} & {$[0.003]$} & {$[0.040]$} & {$[0.018]$} & {$[0.015]$} & {$[0.028]$} \\
\hline \multirow[t]{2}{*}{$\begin{array}{l}\text { Core Deposits (t-1) }^{\prime} \text { Liabilities }_{(t-} \\
\text { 1) }{ }^{*} \text { Facility*Libor-OIS }\end{array}$} & -0.000 & 0.000 & $0.051^{* *}$ & 0.009 & 0.004 & -0.001 & 0.029 & 0.027 & $0.091 * *$ \\
\hline & {$[0.005]$} & {$[0.000]$} & {$[0.022]$} & {$[0.013]$} & {$[0.005]$} & {$[0.040]$} & {$[0.020]$} & {$[0.021]$} & {$[0.038]$} \\
\hline \multirow[t]{2}{*}{ Tier1 Capital $\left.\right|_{(\mathrm{t}-1)} / \mathrm{RWA}_{(\mathrm{t}-1)}$} & 0.004 & 0.000 & 0.014 & $-0.059 *$ & 0.004 & $-0.289 * *$ & $0.096^{*}$ & $0.123 * *$ & 0.060 \\
\hline & {$[0.004]$} & {$[0.000]$} & {$[0.028]$} & {$[0.033]$} & {$[0.012]$} & {$[0.128]$} & {$[0.050]$} & {$[0.059]$} & {$[0.084]$} \\
\hline \multirow[t]{2}{*}{ Tier1 Capital $_{(\mathrm{t}-1)} / \mathrm{RWA}_{(\mathrm{t}-1)} *$ Libor-OIS } & 0.003 & -0.001 & 0.016 & -0.002 & -0.018 & 0.250 & -0.148 & -0.110 & -0.248 \\
\hline & {$[0.003]$} & {$[0.001]$} & {$[0.017]$} & {$[0.063]$} & {$[0.024]$} & {$[0.238]$} & {$[0.170]$} & {$[0.090]$} & {$[0.150]$} \\
\hline \multirow[t]{2}{*}{$\begin{array}{l}\text { Tier1 Capital }{ }_{(\mathrm{t}-1)} / \mathrm{RWA}_{(\mathrm{t}-1)} * \text { Facility*Libor- } \\
\text { OIS }\end{array}$} & -0.004 & 0.000 & 0.011 & $0.104 *$ & 0.022 & 0.135 & 0.031 & 0.064 & $-0.270 * * *$ \\
\hline & {$[0.005]$} & {$[0.000]$} & {$[0.025]$} & {$[0.051]$} & {$[0.020]$} & [0.219] & {$[0.121]$} & {$[0.052]$} & {$[0.091]$} \\
\hline \multirow[t]{2}{*}{ Facility Use } & 0.081 & $0.015^{*}$ & 0.001 & 0.289 & -0.074 & $0.974 * *$ & 0.072 & 0.084 & -0.712 \\
\hline & {$[0.162]$} & {$[0.008]$} & {$[0.375]$} & {$[0.200]$} & {$[0.055]$} & {$[0.362]$} & {$[0.274]$} & {$[0.243]$} & {$[0.737]$} \\
\hline \multirow{2}{*}{ Net Due To (Head Office) $)_{(t-1)} /$ Liabilities $_{(t-1)}$} & & & & -0.015 & -0.004 & 0.028 & -0.010 & 0.034 & $-0.221 * * *$ \\
\hline & & & & {$[0.014]$} & {$[0.003]$} & {$[0.031]$} & {$[0.023]$} & {$[0.020]$} & {$[0.036]$} \\
\hline \multirow[t]{2}{*}{$\begin{array}{l}\text { Net Due To }(\text { Head Office) })_{(\mathrm{t}-1)} / \text { Liabilities }_{(\mathrm{t}-} \\
\text { 1) }{ }^{*} \text { Libor-OIS }\end{array}$} & & & & $0.045 * * *$ & $0.010^{* * *}$ & $0.166^{* * *}$ & $0.059 * * *$ & 0.005 & 0.034 \\
\hline & & & & {$[0.010]$} & {$[0.004]$} & {$[0.055]$} & {$[0.018]$} & {$[0.026]$} & {$[0.046]$} \\
\hline \multirow[t]{2}{*}{$\begin{array}{l}\text { Net Due To }(\text { Head Office) })_{(t-1)} / \text { Liabilities }_{(t-} \\
\text { 1) }{ }^{*} \text { Facility*Libor-OIS }\end{array}$} & & & & $-0.035 * *$ & $-0.008^{*}$ & $-0.130 * *$ & 0.014 & 0.007 & -0.082 \\
\hline & & & & {$[0.013]$} & {$[0.004]$} & {$[0.049]$} & {$[0.020]$} & {$[0.023]$} & {$[0.060]$} \\
\hline Observations & 1,415 & 1,415 & 1,415 & 505 & 505 & 505 & 502 & 483 & 505 \\
\hline R-squared & 0.18 & 0.05 & 0.20 & 0.46 & 0.16 & 0.44 & 0.16 & 0.20 & 0.30 \\
\hline Number of banks & 73 & 73 & 73 & 27 & 27 & 27 & 27 & 27 & 27 \\
\hline Adjusted R-squared & 0.15 & 0.02 & 0.18 & 0.40 & 0.07 & 0.38 & 0.08 & 0.12 & 0.23 \\
\hline Time Period & $\begin{array}{l}\text { 2006Q1- } \\
\text { 2012Q4 }\end{array}$ & $\begin{array}{l}\text { 2006Q1- } \\
\text { 2012Q4 }\end{array}$ & $\begin{array}{l}\text { 2006Q1- } \\
\text { 2012Q4 }\end{array}$ & $\begin{array}{l}\text { 2006Q1- } \\
\text { 2012Q4 }\end{array}$ & $\begin{array}{l}\text { 2006Q1- } \\
\text { 2012Q4 }\end{array}$ & $\begin{array}{l}\text { 2006Q1- } \\
\text { 2012Q4 }\end{array}$ & $\begin{array}{l}\text { 2006Q1- } \\
\text { 2012Q4 }\end{array}$ & $\begin{array}{l}\text { 2006Q2- } \\
\text { 2012Q4 }\end{array}$ & $\begin{array}{l}\text { 2006Q1- } \\
\text { 2012Q4 }\end{array}$ \\
\hline Time fixed effects & Yes & Yes & Yes & Yes & Yes & Yes & Yes & Yes & Yes \\
\hline Bank fixed effects & Yes & Yes & Yes & Yes & Yes & Yes & Yes & Yes & Yes \\
\hline
\end{tabular}




\section{Appendix 4: Credit and Lending Effects of Liquidity Risk without Bank Fixed Effects}

The model specifications for Appendix 2 exclude bank fixed-effects but are otherwise identical to Table 2. This table reports the effects of liquidity risk conditions, central bank facility use, and firm characteristics on growth in domestic and foreign C\&I lending and credit. Panels A and B respectively observe samples of banks without and with foreign affiliates, and Panel B includes additional regressions for changes in aggregate cross-border claims, foreign-office claims, and net due to (or net due from). Reported separately in each panel are the implied marginal effects for periods in which individual institutions used central bank liquidity facilities. The reported coefficients are the linear combination of the coefficients on the respective LIBOR-OIS and LIBOR-OIS*Facility interaction terms. Beginning-of-quarter assets are used to standardize growth in liquid assets, loans, and net due to, while assets and commitments, together, are used to standardize credit growth. The data are quarterly from 2006Q1 to 2012Q4 for a panel of bank holding companies. The panel is restricted to bank holding companies with greater than $\$ 10$ billion in total assets (2012 prices) during its final quarter in the sample. Banks are judged to have a foreign affiliate if they report positive aggregate foreignoffice claims in the FFIEC 009. Banks that report zero foreign-office claims or do not report the FFIEC 009 are considered not to have a foreign affiliate. To mitigate the effect of bank mergers on the dependent variable, banks are excluded in a particular quarter when asset growth exceeds $10 \%$. Firm characteristic data comes from the FR Y9-C and are aggregated to the highest domestic holding company. The net due to (or due from) variable is reported in the FFIEC 031 and measures a bank's total net internal lending (or borrowing) vis-à-vis all its related domestic and international offices from the perspective of the head office. Given that the flows include domestic intra-bank lending, net due to observations are excluded for banks without foreign affiliates. Loan-level data on banks' borrowing through the Discount Window and Term Auction Facility are available through Federal Reserve Board of Governors' website. The LIBOR-OIS is the quarterly average of the daily difference between the London Interbank Offered Rate and the effective federal funds rate. Growth variables are winsorized at the 1st and 99th percentiles. All specifications include time fixed effects. Standard errors are clustered by bank. ***, **, and * respectively indicate significance at the $1 \%, 5 \%$, and $10 \%$ level.

Panel A: Banks without Foreign Affiliates - No Bank Fixed Effects

\begin{tabular}{lccc} 
& $\begin{array}{c}\text { Domestic C\&I } \\
\text { Loans/Assets }\end{array}$ & $\begin{array}{c}\Delta \text { Foreign C\&I } \\
\text { Loans/Assets }\end{array}$ & $\begin{array}{c}\Delta \text { Credit/ } \\
\text { (Assets }+ \\
\text { Commitments) }\end{array}$ \\
Variables & 0.004 & 0.000 & 0.007 \\
\hline Illiquid Assets & 0.000 & 0.000 & 0.020 \\
Illiquid Assets*Libor-OIS & 0.001 & 0.000 & 0.004 \\
Illiquid Assets*Libor-OIS * Facility & -0.002 & 0.000 & -0.008 \\
Commitment Ratio & 0.012 & 0.001 & 0.012 \\
Commitment Ratio*Libor-OIS & -0.006 & -0.001 & -0.024 \\
Commitment Ratio*Libor-OIS*Facility & $-0.085^{*}$ & 0.003 & $-0.551^{* * *}$ \\
Log Real Assets & 0.030 & $-0.011^{* *}$ & 0.358 \\
Log Real Assets*Libor-OIS & 0.004 & -0.001 & -0.164 \\
Log Real Assets*Libor-OIS * Facility & -0.002 & $0.001^{* *}$ & -0.013 \\
Core Deposits & $0.005^{*}$ & $-0.001^{* *}$ & 0.005 \\
Core Deposits*Libor-OIS & -0.004 & 0.000 & 0.036 \\
Core Deposits*Libor-OIS*Facility & -0.002 & 0.000 & -0.017 \\
Tier 1/RWA & 0.004 & -0.001 & 0.020 \\
Tier 1/RWA*Libor-OIS & 0.000 & 0.000 & 0.019 \\
Tier 1/RWA*Libor-OIS*Facility & & & \\
Observations & 1,415 & 1,415 & 1,415 \\
R-squared & 0.17 & 0.05 & 0.19 \\
Number of banks & 73 & 73 & 73 \\
Adjusted R-squared & 0.15 & 0.02 & 0.16 \\
Time Period & & & $2006 \mathrm{Q} 1-$ \\
Time fixed effects & Yes & Yes & Yes \\
Bank fixed effects & No & No & No \\
\hline \hline Central Bank Facility Use & 0.001 & 0.000 & 0.024 \\
Illiquid Assets & 0.006 & 0.000 & -0.012 \\
Commitment Ratio & 0.034 & $-0.012^{* *}$ & 0.194 \\
Log Real Assets & 0.001 & $-0.001 * *$ & 0.040 \\
Core Deposits & 0.004 & -0.001 & 0.039 \\
Tier 1/RWA & & & \\
\hline & $2006 \mathrm{Q} 1-2012 \mathrm{Q} 4$ & $2012 \mathrm{Q}$ \\
\hline
\end{tabular}


Panel B: Banks with Foreign Affiliates - No Bank Fixed Effects

\begin{tabular}{|c|c|c|c|c|c|c|}
\hline Variables & $\begin{array}{c}\Delta \text { Domestic } \\
\text { C\&I } \\
\text { Loans/Assets } \\
\end{array}$ & $\begin{array}{c}\Delta \text { Foreign } \\
\text { C\&I } \\
\text { Loans/Assets }\end{array}$ & $\begin{array}{c}\Delta \text { Credit/ } \\
\text { (Assets + } \\
\text { Commitments) }\end{array}$ & $\begin{array}{c}\Delta \text { Cross- } \\
\text { border } \\
\text { Claims/Assets } \\
\end{array}$ & $\begin{array}{c}\Delta \text { Foreign- } \\
\text { office } \\
\text { Claims/Assets }\end{array}$ & $\begin{array}{c}\Delta \text { Net Due To } \\
\text { (Head } \\
\text { Office)/ } \\
\text { Assets }\end{array}$ \\
\hline Illiquid Assets & 0.016 & $0.008 * *$ & 0.077 & $0.063 * * *$ & 0.036 & -0.026 \\
\hline Illiquid Assets*Libor-OIS & -0.025 & $-0.009 * * *$ & -0.020 & $-0.054 * *$ & $-0.050 * *$ & -0.040 \\
\hline Illiquid Assets*Libor-OIS * Facility & 0.005 & 0.000 & $0.053^{*}$ & -0.007 & -0.010 & -0.004 \\
\hline Commitment Ratio & -0.007 & 0.002 & -0.086 & $0.040^{* *}$ & 0.018 & 0.031 \\
\hline Commitment Ratio*Libor-OIS & 0.009 & -0.004 & 0.052 & -0.018 & $-0.032 * * *$ & -0.006 \\
\hline Commitment Ratio*Libor-OIS*Facility & $-0.140 * * *$ & 0.002 & $-0.521 * * *$ & $0.119^{*}$ & 0.095 & -0.046 \\
\hline Log Real Assets & $0.156^{* *}$ & -0.016 & 0.569 & $-0.422 * * *$ & $-0.312 *$ & -0.183 \\
\hline Log Real Assets*Libor-OIS & -0.009 & 0.022 & 0.002 & 0.142 & $0.153^{* *}$ & 0.064 \\
\hline Log Real Assets*Libor-OIS*Facility & -0.002 & 0.000 & 0.011 & 0.001 & 0.005 & -0.013 \\
\hline Core Deposits & 0.004 & -0.002 & 0.022 & -0.026 & -0.015 & 0.033 \\
\hline Core Deposits*Libor-OIS & 0.015 & $0.007 *$ & -0.008 & $0.037 *$ & 0.035 & 0.024 \\
\hline Core Deposits*Libor-OIS*Facility & -0.013 & 0.003 & -0.111 & 0.055 & 0.052 & 0.065 \\
\hline Tier 1/RWA & -0.034 & -0.011 & 0.183 & -0.143 & -0.088 & -0.261 \\
\hline Tier 1/RWA*Libor-OIS & 0.092 & 0.016 & -0.040 & 0.016 & 0.032 & 0.154 \\
\hline Tier 1/RWA*Libor-OIS*Facility & $-0.013 * * *$ & $-0.003 * * *$ & -0.003 & $-0.021 * * *$ & 0.011 & 0.011 \\
\hline Net Due To (Head Office) & $0.043 * * *$ & $0.011 * * *$ & $0.150^{* *}$ & $0.069 * * *$ & 0.001 & 0.015 \\
\hline Net Due To (Head Office)*Libor-OIS & $-0.023 *$ & -0.007 & -0.077 & 0.006 & -0.001 & $-0.115 * *$ \\
\hline Net Due To (Head Office)*Libor-OIS*Facility & $0.000 * * *$ & $0.000 * * *$ & $0.000 * * *$ & $0.000 * * *$ & $0.000 * * *$ & $0.000 * * *$ \\
\hline Observations & 505 & 505 & 505 & 502 & 483 & 505 \\
\hline R-squared & 0.40 & 0.15 & 0.39 & 0.18 & 0.20 & 0.14 \\
\hline Number of banks & 27 & 27 & 27 & 27 & 27 & 27 \\
\hline $\begin{array}{l}\text { Adjusted R-squared } \\
\text { Time Period }\end{array}$ & $\begin{array}{c}0.34 \\
\text { 2006Q1- } \\
\text { 2012Q4 }\end{array}$ & $\begin{array}{c}0.06 \\
\text { 2006Q1- } \\
\text { 2012Q4 }\end{array}$ & $\begin{array}{c}0.33 \\
\text { 2006Q1- } \\
\text { 2012Q4 }\end{array}$ & $\begin{array}{c}0.09 \\
\text { 2006Q1- } \\
\text { 2012Q4 }\end{array}$ & $\begin{array}{c}0.12 \\
\text { 2006Q2- } \\
\text { 2012Q4 }\end{array}$ & $\begin{array}{c}0.06 \\
\text { 2006Q1- } \\
\text { 2012Q4 }\end{array}$ \\
\hline Time fixed effects & Yes & Yes & Yes & Yes & Yes & Yes \\
\hline Bank fixed effects & No & No & No & No & No & No \\
\hline \multicolumn{7}{|l|}{ Central Bank Facility } \\
\hline Illiquid Assets & -0.009 & -0.001 & $0.057^{*}$ & 0.008 & -0.014 & $-0.065^{* *}$ \\
\hline Commitment Ratio & 0.001 & -0.002 & -0.034 & $0.023 * *$ & -0.014 & 0.025 \\
\hline Log Real Assets & $0.147 * *$ & 0.006 & 0.571 & $-0.279 * *$ & -0.159 & -0.119 \\
\hline Core Deposits & $0.019^{* *}$ & 0.004 & 0.013 & 0.011 & 0.020 & $0.057^{* *}$ \\
\hline Tier 1/RWA & $0.058^{*}$ & 0.005 & 0.144 & $-0.127 *$ & -0.056 & -0.107 \\
\hline Net Due To (Head Office) & 0.019 & 0.003 & 0.073 & $0.075 * * *$ & 0.000 & $-0.099 * * *$ \\
\hline
\end{tabular}




\section{Appendix 5: Underlying Regressions for International Claims and Liquidity Risk, using Bank-Location-Specific Data}

This table reports fixed effects regressions of quarterly growth in country-specific cross-border and foreign-office claims on LIBOR-OIS, central bank facility access, firm characteristics, and interactions. The coefficients reported reflect the underlying results for Table 3. Beginning-ofquarter assets are used to standardize growth in the dependent variables. Cross-border and foreign-office claims are measured on an immediate counterparty basis. The data are observed quarterly from 2006Q2 to 2012Q4 for a panel of U.S. bank holding companies. The panel is restricted to bank-holding companies with greater than $\$ 10$ billion in total assets (2012 prices) during its final quarter in the sample. For growth in foreignoffice claims, the sample excludes observations when country-specific foreign-office claims are zero in both the current and previous quarter. To mitigate the effect of bank mergers on the dependent variables, banks are excluded in quarters when asset growth exceeds $10 \%$. Firm characteristic data comes from the FR Y9-C and are aggregated to the highest domestic holding company. Data on country-specific bank exposures are from the FFIEC 009. The net due to (or due from) variable measures a bank's total net internal lending (or borrowing) vis-à-vis all its related offices in other countries. Reported in the FFIEC 009, these flows reflect the perspective of the foreign office. International claims are consolidated into regional aggregates for smaller and static exposures. Exposures to a particular country are grouped into a regional aggregate if total cross-border claims are less than $\$ 2$ billion across all banks and quarters in the sample or there is zero growth in cross-border claims, at the bank level, for greater than $30 \%$ of the observations in the sample for the particular country. Exposures to Caribbean countries are also excluded. Loan-level data on banks' borrowing through the Discount Window and Term Auction Facility are available through Federal Reserve Board of Governors' website. The LIBOR-OIS is the quarterly average of the daily difference between the London Interbank Offered Rate and the effective federal funds rate. Growth variables are winsorized at the 1st and 99th percentiles. All specifications include country-time and bank fixed effects. Standard errors are clustered by bank. ***, **, and * respectively indicate significance at the $1 \%, 5 \%$, and $10 \%$ level. The dependent variables, originally reported in growth relative to assets (percent), have been multiplied by a factor of 1,000 .

\begin{tabular}{|c|c|c|}
\hline VARIABLES & $\begin{array}{c}(1) \\
\Delta \text { Cross- } \\
\text { border } \\
\text { Claims/Assets }\end{array}$ & $\begin{array}{c}(2) \\
\Delta \text { Foreign- } \\
\text { office } \\
\text { Claims/Assets }\end{array}$ \\
\hline Illiquid Assets $_{(\mathrm{t}-1)} /$ Assets $_{(\mathrm{t}-1)}$ & $\begin{array}{l}-0.237 \\
{[0.271]}\end{array}$ & $\begin{array}{c}1.880 \\
{[1.215]}\end{array}$ \\
\hline Illiquid Assets $_{(\mathrm{t}-1)} / \operatorname{Assets}_{(\mathrm{t}-1)} *$ LIBOR-OIS & $\begin{array}{c}0.508 * * * \\
{[0.183]}\end{array}$ & $\begin{array}{c}-0.640 \\
{[2.069]}\end{array}$ \\
\hline Commitment Ratio $_{(t-1)}$ & $\begin{array}{l}-0.288 \\
{[0.338]}\end{array}$ & $\begin{array}{l}-2.463^{*} \\
{[1.236]}\end{array}$ \\
\hline Commitment Ratio $_{(\mathrm{t}-1)} *$ LIBOR-OIS & $\begin{array}{c}0.330 \\
{[0.385]}\end{array}$ & $\begin{array}{c}2.666 \\
{[3.097]}\end{array}$ \\
\hline $\log _{\text {Real Assets }}^{(\mathrm{t}-1)}$ & $\begin{array}{l}-0.233 \\
{[2.102]}\end{array}$ & $\begin{array}{c}32.798 \\
{[28.558]}\end{array}$ \\
\hline Log Real Assets $(\mathrm{t}-1)$ LIBOR-OIS & $\begin{array}{c}-4.603^{* *} \\
{[2.189]}\end{array}$ & $\begin{array}{l}-20.571 \\
{[17.349]}\end{array}$ \\
\hline Core Deposits $_{(\mathrm{t}-1)} /$ Liabilities $_{(\mathrm{t}-1)}$ & $\begin{array}{c}0.499 * * \\
{[0.195]}\end{array}$ & $\begin{array}{c}2.606 \\
{[1.827]}\end{array}$ \\
\hline Core Deposits $_{(\mathrm{t}-1)} /$ Liabilities $_{(\mathrm{t}-1)} *$ LIBOR-OIS & $\begin{array}{l}-0.193 \\
{[0.163]}\end{array}$ & $\begin{array}{l}1.253 \\
{[1.880]}\end{array}$ \\
\hline Tier1 Capital $_{(\mathrm{t}-1)} / \mathrm{RWA}_{(\mathrm{t}-1)}$ & $\begin{array}{l}1.118^{*} \\
{[0.565]}\end{array}$ & $\begin{array}{c}5.241 \\
{[4.017]}\end{array}$ \\
\hline Tier1 Capital $(t-1) / \mathrm{RWA}_{(\mathrm{t}-1)} *$ LIBOR-OIS & $\begin{array}{l}-0.915 \\
{[0.650]}\end{array}$ & $\begin{array}{l}-6.376 \\
{[4.827]}\end{array}$ \\
\hline Net Due To (Foreign Office) $_{(\mathrm{t}-1)} /$ Liabilities $_{(\mathrm{t}-1)}$ & $\begin{array}{c}2.456 * * * \\
{[0.892]}\end{array}$ & $\begin{array}{c}1.414 \\
{[1.086]}\end{array}$ \\
\hline 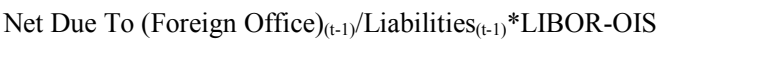 & $\begin{array}{c}2.258 \\
{[16.752]}\end{array}$ & $\begin{array}{l}49.699 \\
{[32.832]}\end{array}$ \\
\hline Illiquid Assets $_{(\mathrm{t}-1)} /$ Assets $_{(\mathrm{t}-1)} *$ Facility*LIBOR-OIS & $\begin{array}{c}0.057 \\
{[0.228]}\end{array}$ & $\begin{array}{l}-2.152 \\
{[2.140]}\end{array}$ \\
\hline Commitment Ratio $_{(\mathrm{t}-1)} *$ Facility*LIBOR-OIS & $\begin{array}{c}0.067 \\
{[0.347]}\end{array}$ & $\begin{array}{c}1.651 \\
{[2.617]}\end{array}$ \\
\hline Log Real Assets(t-1) $*$ Facility*LIBOR-OIS & $\begin{array}{c}0.818 \\
{[0.949]}\end{array}$ & $\begin{array}{l}-2.228 \\
{[5.438]}\end{array}$ \\
\hline Core Deposits $_{(\mathrm{t}-1)} /$ Liabilities $_{(\mathrm{t}-1)} *$ Facility $^{*}$ LIBOR-OIS & $\begin{array}{c}-0.281 \\
{[0.255]}\end{array}$ & $\begin{array}{c}2.020 \\
{[2.321]}\end{array}$ \\
\hline $\operatorname{Tier1~Capital~}_{(\mathrm{t}-1)} / \mathrm{RWA}_{(\mathrm{t}-1)} *$ Facility*LIBOR-OIS & $\begin{array}{l}-1.016 \\
{[1.094]}\end{array}$ & $\begin{array}{c}4.403 \\
{[4.930]}\end{array}$ \\
\hline Net Due To $(\text { Foreign Office) })_{(\mathrm{t}-1)} /$ Liabilities $_{(\mathrm{t}-1)} *$ Facility*LIBOR-OIS & $\begin{array}{l}33.364 * * \\
{[13.718]}\end{array}$ & $\begin{array}{l}-43.335 \\
{[40.759]}\end{array}$ \\
\hline Core Funding & $6.821 *$ & $26.783 * *$ \\
\hline
\end{tabular}




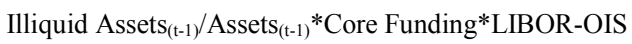

[4.037] [12.533]

Commitment Ratio(t-1) $*$ Core Funding*LIBOR-OIS

$-0.465 \quad-0.559$

[0.747] [2.928]

$0.691 \quad 2.742$

[0.631] [2.615]

Log Real Assets(t-1) $*$ Core Funding*LIBOR-OIS

$-1.043 \quad-3.040$

Core Deposits $(\mathrm{t}-1)_{\text {Liabilities }_{(\mathrm{t}-1)}} *$ Core Funding*LIBOR-OIS

[0.939] [2.614]

$0.877 \quad-0.296$

Tier1 Capital $\mathrm{t}_{(\mathrm{t}-1)} / \mathrm{RWA}_{(\mathrm{t}-1)} *$ Core Funding*LIBOR-OIS

[0.642] [2.507]

$-0.134 \quad-4.220$

Net Due To (Foreign Office) $)_{(\mathrm{t}-1)} /$ Liabilities $_{(\mathrm{t}-1)} *$ Core Funding*LIBOR-OIS

[1.678]

$-26.295^{*}$

[13.853]

Illiquid Assets $_{(\mathrm{t}-1)} /$ Assets $_{(\mathrm{t}-1)} *$ Core Funding*Facility*LIBOR-OIS

$-0.536$

[0.844]

$-0.596$

[0.774]

0.456

[1.592]

0.275

[0.751]

1.704

[2.614]

Tier1 Capital $1_{(\mathrm{t}-1)} / \mathrm{RWA}_{(\mathrm{t}-1)} *$ Core Funding*Facility*LIBOR-OIS

Net Due To (Foreign Office) $)_{(\mathrm{t}-1)} /$ Liabilities $_{(\mathrm{t}-1)} *$ Core Funding $^{*}$ Facility*LIBOR-OIS

$-11.681$

[12.591]

Core Investment

$-24.740$

[15.457]

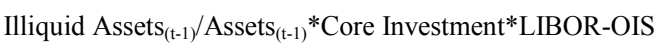

$10.136^{* * *}$

[2.933]

$-1.334$

[2.743]

$-20.918^{* * *}$

[6.528]

Log Real Assets $_{(\mathrm{t}-1)} *$ Core Investment*LIBOR-OIS

Core Deposits $_{(\mathrm{t}-1)} /$ Liabilities $_{(\mathrm{t}-1)} *$ Core Investment*LIBOR-OIS $^{*}$

Tier1 Capital $(\mathrm{t}-1) / \mathrm{RWA}_{(\mathrm{t}-1)} *$ Core Investment*LIBOR-OIS

Net Due To (Foreign Office) $)_{(\mathrm{t}-1)} /$ Liabilities $_{(\mathrm{t}-1)} *$ Core Investment*LIBOR-OIS

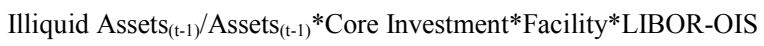

$-6.050 * * *$

[1.643]

$-12.443$

[9.597]

$58.862 * * *$

[17.821]

$-7.591$

[4.823]

$7.030 * *$

[2.956]

5.226

[16.719]

$7.411 * *$

[2.851]

$-6.838$

[14.534]

$-126.380^{* * *}$

[19.967]

2.676

[4.441]

[4.309]

$-59.945^{*}$

[32.386]

1.770

[2.823]

-4.398 *

[2.248]

0.791

[5.273]

$-0.113$

[2.341]

8.266

[6.993]

54.836

[45.692]

167.534

[170.486]

7.465

[6.798]

$-3.474$

[7.176]

$-20.404$

[20.434]

1.068

[5.560]

$-17.869$

[21.342]

$-81.810$

[50.861]

$-16.732 *$

[8.721]

$-19.971$

[15.446]

66.873

[47.921]

12.385

[14.041]

$-24.172$

[48.429]

128.528

[85.947]

18.198

Facility Use

[29.691]

Observations

22,171

5,911

R-squared

Number of banks

Bank fixed effects

0.10

0.19

$\begin{array}{ll}41 & 27\end{array}$

Yes Yes

Country-time fixed effects

Yes 